Article

\title{
The Cost of Clean Water in the Delaware River Basin (USA)
}

\author{
Gerald J. Kauffman 10 \\ Water Resources Center, School of Public Policy and Administration, University of Delaware, \\ Newark, DE 19716, USA; jerryk@udel.edu; Tel.: +1-302-831-4929
}

Received: 22 September 2017; Accepted: 8 January 2018; Published: 24 January 2018

\begin{abstract}
The Delaware River has made a marked recovery in the half-century since the adoption of the Delaware River Basin Commission (DRBC) Compact in 1961 and passage of the Federal Clean Water Act amendments during the 1970s. During the 1960s, the DRBC set a $3.5 \mathrm{mg} / \mathrm{L}$ dissolved oxygen criterion for the river based on an economic analysis that concluded that a waste load abatement program designed to meet fishable water quality goals would generate significant recreational and environmental benefits. Scientists with the Delaware Estuary Program have recently called for raising the 1960s dissolved oxygen criterion along the Delaware River from $3.5 \mathrm{mg} / \mathrm{L}$ to $5.0 \mathrm{mg} / \mathrm{L}$ to protect anadromous American shad and Atlantic sturgeon, and address the prospect of rising temperatures, sea levels, and salinity in the estuary. This research concludes, through a nitrogen marginal abatement cost (MAC) analysis, that it would be cost-effective to raise dissolved oxygen levels to meet a more stringent standard by prioritizing agricultural conservation and some wastewater treatment investments in the Delaware River watershed to remove $90 \%$ of the nitrogen load by 13.6 million $\mathrm{kg} \mathrm{N} /$ year (30 million $\mathrm{lb} \mathrm{N} /$ year) for just 35\% (\$160 million) of the $\$ 449$ million total cost. The annual least cost to reduce nitrogen loads and raise dissolved oxygen levels to meet more stringent water quality standards in the Delaware River totals $\$ 45$ million for atmospheric NOX reduction, \$130 million for wastewater treatment, \$132 million for agriculture conservation, and $\$ 141$ million for urban stormwater retrofitting. This 21 st century least cost analysis estimates that an annual investment of $\$ 50$ million is needed to reduce pollutant loads in the Delaware River to raise dissolved oxygen levels to $4.0 \mathrm{mg} / \mathrm{L}, \$ 150$ million is needed for dissolved oxygen levels to reach $4.5 \mathrm{mg} / \mathrm{L}$, and $\$ 449$ million is needed for dissolved oxygen levels to reach $5.0 \mathrm{mg} / \mathrm{L}$.
\end{abstract}

Keywords: river basin; water quality; water pollution; economic valuation

\section{Introduction}

Nutrient pollution due to high loads of nitrogen and phosphorus causes costly impacts on the tourism, commercial fishing, recreation, hunting, real estate, and water treatment sectors of the economy [1]. Noting that $50 \%$ of the nation's streams have medium to high nutrient levels and $78 \%$ of coastal waters experience eutrophication, the Environmental Protection Agency (EPA) has urged states to adopt numeric nutrient criteria to reduce nitrogen and phosphorus loads on U.S. waters [2].

Nutrient load reduction costs in the nation's waters are significant and range from $\$ 35$ million/year in the $16,500 \mathrm{~km}^{2}$ Wisconsin Fox-Wolf River watershed [3] to $\$ 203$ million/year in the $26,200 \mathrm{~km}^{2}$ Connecticut River/Long Island Sound Basin [4]. The Chesapeake Bay Program [5] estimated that restoration of the $166,000 \mathrm{~km}^{2}$ Chesapeake Bay watershed could cost $\$ 1$ billion/year. Rabotyagov et al. [6] estimated a cost of $\$ 1.8$ billion/year to reduce nutrient loads and increase dissolved oxygen levels in the $492,000 \mathrm{~km}^{2}$ Upper Mississippi River Basin. Lyon and Farrow [7] reported to the EPA that the Federal Clean Water Act stormwater programs could cost up to $\$ 14$ billion/year nationwide.

The Interstate Commission on the Delaware River Basin [8] once called the Delaware River near Philadelphia "one of the most grossly polluted areas in the United States." In 1961, President John 
F. Kennedy and the governors of Delaware, New Jersey, New York, and Pennsylvania signed the Delaware River Basin Commission (DRBC) Compact as one of the first models of Federalism or shared power in water management between the Federal government and the states [9]. For over half a century, the DRBC has been empowered by this compulsory 1961 Federal/state compact to oversee water pollution control programs on the Delaware River [10,11].

Water quality has been impaired by nutrient pollution [12-16] but the estuary has recovered in the last several decades due to restoration efforts by DRBC, EPA, and the states [17-19]. A century-long water quality record reconstructed by Sharp [20] indicates that the tidal Delaware has made one of the most extensive recoveries of any estuary in the world as dissolved oxygen levels declined to zero during the 1950s and 1960s and increased to near $400 \mu \mathrm{mol} / \mathrm{L}$ by the turn of the 21st century.

While pollutant loadings have decreased and water quality has measurably improved in the Delaware Estuary since the adoption of the 1961 DRBC Compact, dissolved oxygen levels still do not fully meet the criterion of $3.5 \mathrm{mg} / \mathrm{L}$ during the summer when dissolved oxygen saturation declines with warming water temperatures. Scientists with the Delaware Estuary Program and the DRBC have discussed setting more rigorous dissolved oxygen criteria along the tidal Delaware River (to at least $5.0 \mathrm{mg} / \mathrm{L}$ ) to protect the year-round propagation of anadromous fish such as the American shad and Atlantic sturgeon [21,22]. More stringent dissolved oxygen criteria would also address the prospect of atmospheric warming and rising sea levels that are projected to increase water temperatures, raise salinity, and further depress dissolved oxygen saturation.

While dissolved oxygen levels have recovered over the last half-century, little is known about modern costs to restore the Delaware River to meet fishable water quality standards. The objectives of this research are to estimate the costs of investments to reduce pollutant loads and restore the Delaware River to meet more protective year-round fishable dissolved oxygen criteria in accordance with DRBC, $\mathrm{EPA}$, and state water quality standards.

\section{The Delaware River}

While just the 33rd largest river in the United States, the Delaware River is the longest undammed river east of the Mississippi, extending $390 \mathrm{mi}(628 \mathrm{~km})$ from the $3000 \mathrm{ft}(970 \mathrm{~m})$ high Catskill Mountains in New York State to the mouth of the Delaware Bay at Cape May, New Jersey. The river is fed by 216 streams including its two largest tributaries (the Schuylkill and Lehigh River) and drains $13,539 \mathrm{mi}^{2}$ $\left(35,077 \mathrm{~km}^{2}\right)$ in Delaware, Pennsylvania, New Jersey, New York, and a small part of Maryland.

The Delaware Basin covers just $0.4 \%$ of the continental U.S., yet supplies drinking water to $5 \%$ of the nation's population and the first (New York City) and seventh (Philadelphia) largest metropolitan economies in the nation [23]. Over 16 million people rely on the Delaware Basin for drinking water, including 8.2 million people who live in the watershed and 8 million people who live outside the basin in New York City and central New Jersey. Between 2000 and 2010, the population in the Delaware Basin increased by half a million people, an amount equal to the combined population of the cities of Camden, Trenton, and Wilmington.

The Delaware Estuary extends $130 \mathrm{mi}(208 \mathrm{~km})$ from the Atlantic Ocean to the head of tide at Trenton [24]. High nutrient loads discharged from tributaries near Philadelphia and rural streams along the bay are diluted by saltwater as the estuary widens toward the mouth of the bay [13]. The Delaware Estuary recirculates every 8 days (Table 1) with half mixing with freshwater from the Delaware River at Trenton, Schuylkill, Lehigh, Brandywine, and smaller tributaries and the other half from the Atlantic Ocean [17]. The estuary is relatively turbid with a light extinction coefficient of $0.3-7.0$ [25]. 
Table 1. Characteristics of the Delaware River $[17,25]$.

\begin{tabular}{cc}
\hline Characteristic & Value \\
\hline Drainage Area $\left(\mathrm{km}^{2}\right)$ & 35,252 \\
Population $(2010)$ & $8,200,000$ \\
Total Length $(\mathrm{km})$ & 628 \\
Tidal Length $(\mathrm{km})$ & 155 \\
Watershed/Estuary Ratio & 18 \\
Estuary Recirculation (days) & 8 \\
Light Extinction Coefficient & $0.3-7.0$ \\
\hline
\end{tabular}

The DRBC [26,27] classifies the Delaware River and Bay according to 10 nontidal and tidal water quality management zones based on (a) Agricultural, Industrial, and Public Water Supply; (b) Wildlife, Fish and Aquatic Life; (c) Recreation (Swimming, Boating, Fishing, Wading); (d) Navigation; and (e) Waste Assimilation designated uses (Figure 1). In the tidal Delaware, the summer dissolved oxygen criterion varies from $3.5 \mathrm{mg} / \mathrm{L}$ in Zones 3 and 4 (from Rancocas Creek past Philadelphia to Wilmington) to $4.5 \mathrm{mg} / \mathrm{L}$ in Zone 5 (from Wilmington to the Chesapeake \& Delaware Canal). Minimum dissolved oxygen criteria are $6.5 \mathrm{mg} / \mathrm{L}$ during spring and fall in Zones 2 through 5 to allow for seasonal spawning and propagation of resident and anadromous fish.

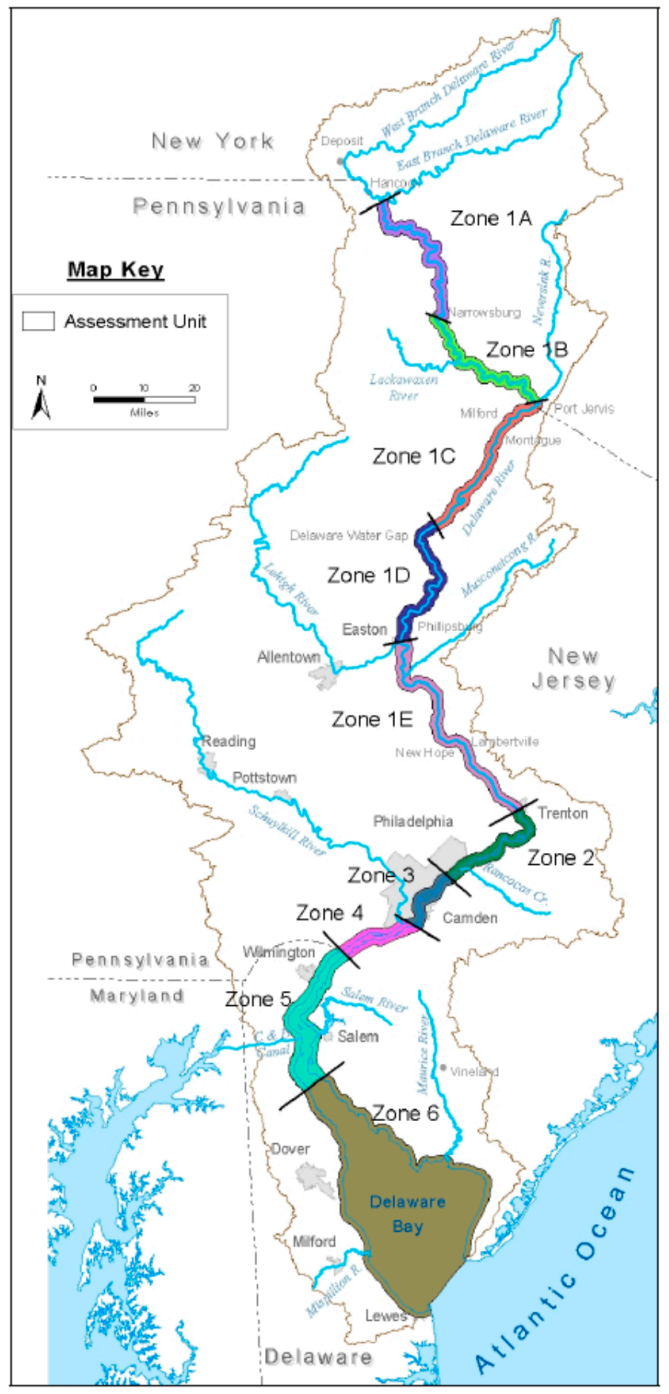

Figure 1. Delaware River water quality management zones [27]. 
Despite high nutrient loading, the Delaware Estuary does not exhibit classic eutrophication symptoms of hypoxia or algal blooms as observed in the nearby Chesapeake Bay. Algal blooms are inhibited by the assimilative capacity of wetlands that rim the Delaware Bay and by low light levels in the well-flushed and turbid Delaware Estuary. Through the wide $17 \mathrm{mi}(27 \mathrm{~km}) \mathrm{mouth}$ of Delaware Bay, the Atlantic Ocean contributes significant tidal flushing, thus limiting algal blooms that cause fish kills except during an occasional spring bloom in the mid estuary [17].

During the 1960s when the river was anoxic and a decade before the 1970s Federal Clean Water Act Amendments, the DRBC imposed waste load allocations on 80 dischargers and adopted the first interstate water quality standards along the Delaware River. The Federal Water Pollution Control Administration (FWPCA) and Harvard Water Program [28-31] issued an economic report in 1966 that concluded that water supply and recreation benefits due to improved water quality in the Delaware River would exceed water pollution control costs [32-35].

The 1966 FWPCA study estimated pollutant reduction costs ranged from $\$ 150$ million to achieve a dissolved oxygen level of $2.5 \mathrm{mg} / \mathrm{L}$ to $\$ 490$ million to achieve a dissolved oxygen criterion of $4.5 \mathrm{mg} / \mathrm{L}$ with diminishing marginal costs of improvement occurring at dissolved oxygen of $3.0 \mathrm{mg} / \mathrm{L}$ (Table 2). Thomann [33] estimated that shad passage would achieve $80 \%$ survival if dissolved oxygen improved from $0.5 \mathrm{mg} / \mathrm{L}$ in 1964 to a future level of $3.0 \mathrm{mg} / \mathrm{L}$. In 1967, the DRBC considered this economic analysis and set the current dissolved oxygen standard of $3.5 \mathrm{mg} / \mathrm{L}$ in the Delaware River near Philadelphia to support the spring and fall migration of anadromous fish. In 1968, the DRBC quite presciently anticipated that the waste load abatement plan would remove $85 \%$ to $90 \%$ of carbonaceous BOD and boost dissolved oxygen from near zero to $4.0 \mathrm{mg} / \mathrm{L}$ at Philadelphia (Figure 2).

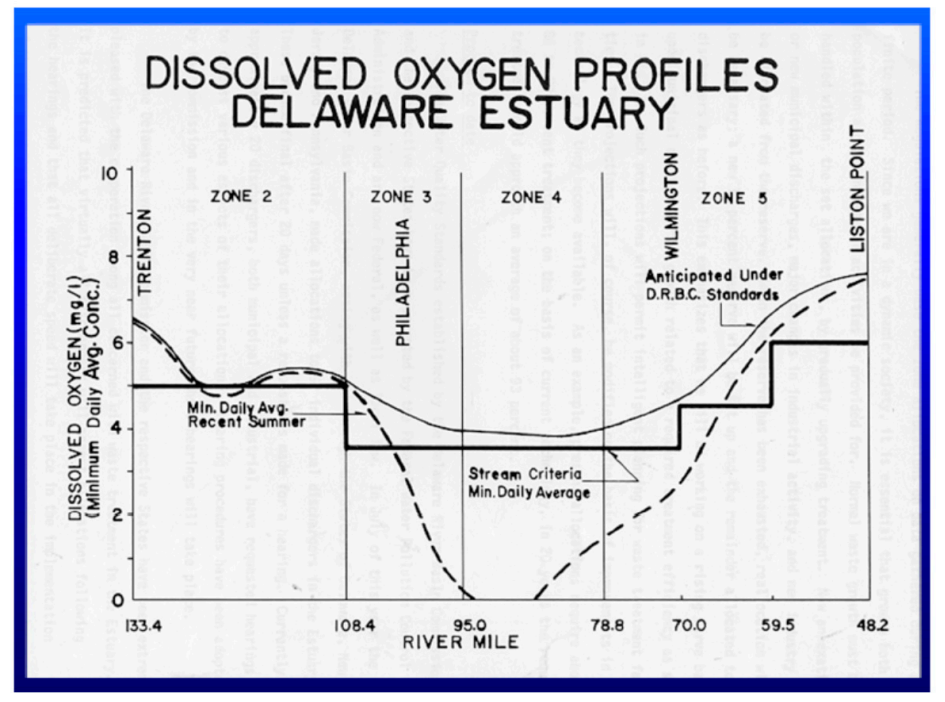

Figure 2. Delaware River Basin Commission (DRBC) dissolved oxygen criteria along the Delaware Estuary in 1968 [22].

Table 2. Costs to meet water quality objectives in the Delaware Estuary [28].

\begin{tabular}{|c|c|c|c|c|c|c|c|}
\hline \multirow{2}{*}{ Objective Set } & \multirow{2}{*}{$\begin{array}{c}\text { Dissolved } \\
\text { Oxygen Criteria } \\
(\mathrm{mg} / \mathrm{L})\end{array}$} & \multicolumn{2}{|c|}{ BOD/COD Residual } & \multirow{2}{*}{$\begin{array}{c}\% \text { BOD } / C O D \\
\text { Pollution } \\
\text { Removal }\end{array}$} & \multirow{2}{*}{$\begin{array}{l}\text { Total Costs } \\
\text { (\$1964) } \\
\text { (\$M/Year) }\end{array}$} & \multirow{2}{*}{$\begin{array}{c}\text { Marginal } \\
\text { Costs (\$1964) } \\
\text { (\$M/Year) }\end{array}$} & \multirow{2}{*}{$\begin{array}{c}\text { \% Survival } \\
\text { Shad Passage }\end{array}$} \\
\hline & & (lb/Day) & (kg/Day) & & & & \\
\hline I. & 4.5 & 100,000 & 45,360 & $92-98 \%$ & 490 & $160-260$ & \\
\hline II. & 4.0 & 200,000 & 90,720 & $90 \%$ & $230-330$ & $100-150$ & $90 \%$ \\
\hline III. & 3.0 & 500,000 & 226,800 & $75 \%$ & $130-180$ & $30-30$ & $80 \%$ \\
\hline IV. & 2.5 & 800,000 & 362,880 & $50 \%$ & $100-150$ & $70-120$ & \\
\hline V. & 0.5 & status quo & & & 30 & 0 & $20 \%$ \\
\hline
\end{tabular}

Dissolved oxygen levels in the Delaware Estuary vary by water temperature, sunlight, winds, and pollutant loads [1]. By 2010, dissolved oxygen levels in the Delaware River at Ben Franklin Bridge 
at Philadelphia mostly exceeded the criterion except for violations below $3.5 \mathrm{mg} / \mathrm{L}$ during the hot summer months of June through August (Figure 3). During warm summers, $0.5 \%$ of readings since 2000 did not meet the $3.5 \mathrm{mg} / \mathrm{L}$ criterion. In July and August, dissolved oxygen in the Delaware River at Philadelphia occasionally declined below the $3.5 \mathrm{mg} / \mathrm{L}$ criterion ( $46 \%$ dissolved oxygen saturation) when water temperatures approached $30^{\circ} \mathrm{C}$ or $86^{\circ} \mathrm{F}$ (Figure 4 ). At $30^{\circ} \mathrm{C}$, dissolved oxygen is $100 \%$ saturated at $7.54 \mathrm{mg} / \mathrm{L}$ and $80 \%$ saturated at $6 \mathrm{mg} / \mathrm{L}$; therefore, when water temperatures rise to $30{ }^{\circ} \mathrm{C}$, a future DRBC dissolved oxygen standard higher than $5 \mathrm{mg} / \mathrm{L}$ (66\% saturation) may prove difficult to achieve given the warm water temperatures that occur during summer.

Scientists on the Delaware Estuary Program Science and Technical Advisory Committee have recommended that the DRBC raise the fishable dissolved oxygen standard from the current level of $3.5 \mathrm{mg} / \mathrm{L}$ to at least $5.0 \mathrm{mg} / \mathrm{L}$ in Zones 3 and 4 from Philadelphia to Wilmington, given that the literature suggests that the current dissolved oxygen criterion of $3.5 \mathrm{mg} / \mathrm{L}$ is too low to support the year-round survival of anadromous shad and sturgeon [36,37]. Secor and Gunderson [38] found that juvenile Atlantic sturgeon may suffer over $50 \%$ mortality at $25^{\circ} \mathrm{C}\left(77^{\circ} \mathrm{F}\right)$ when dissolved oxygen is $3.5 \mathrm{mg} / \mathrm{L}$. Juvenile shortnose sturgeon are prone to $50 \%$ mortality when dissolved oxygen declines below $3.0 \mathrm{mg} / \mathrm{L}$ at $25^{\circ} \mathrm{C}$ [39]. In 2017, the DRBC passed a resolution authorizing basin commission scientists to begin reviewing water quality regulations to determine whether dissolved oxygen criteria should be increased from the current $3.5 \mathrm{mg} / \mathrm{L}$ to a higher level to provide more protection of anadromous fish spawning and year-round propagation of the fishery.

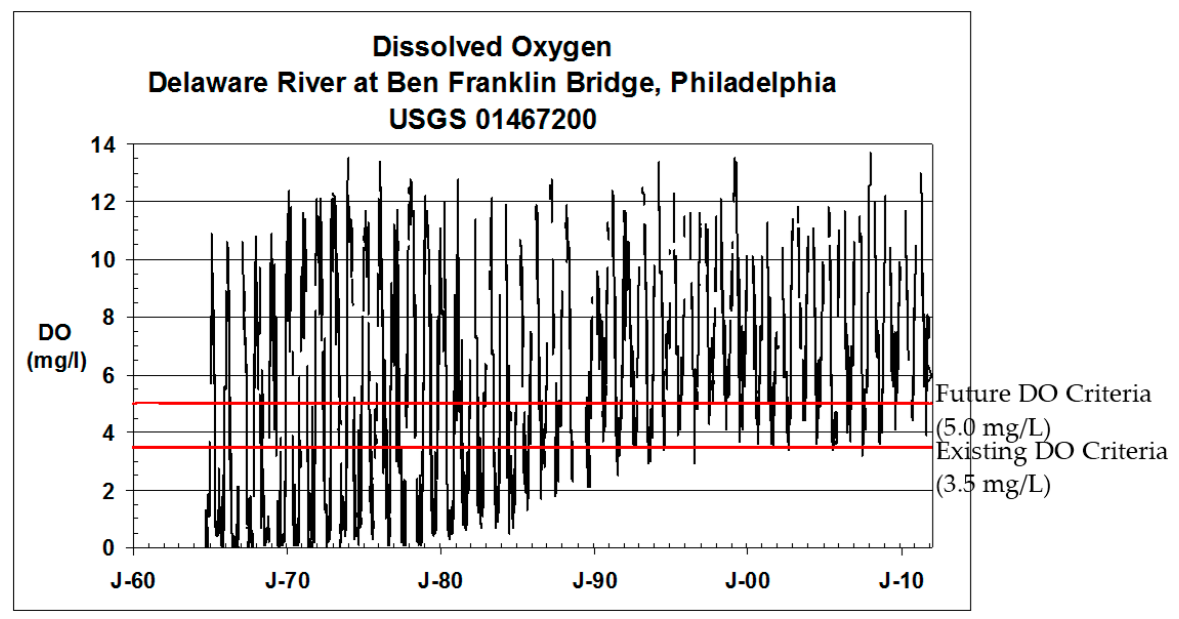

Figure 3. Mean Daily Dissolved Oxygen (DO) at Ben Franklin Bridge along Delaware River.

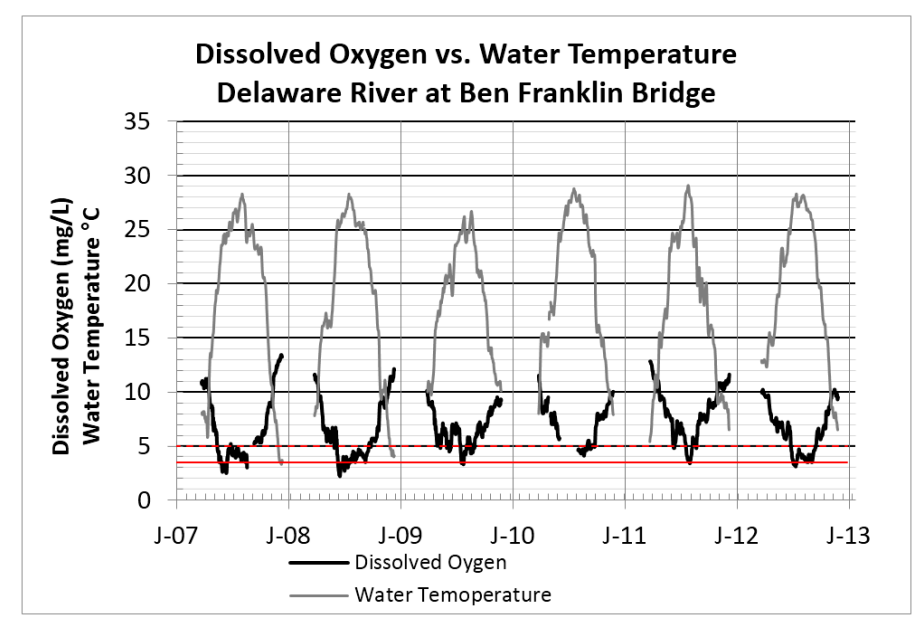

Figure 4. Water temperature/dissolved oxygen along the Delaware River. 


\section{Research Objectives}

While dissolved oxygen levels have recovered over the last half-century, little is known about modern costs to restore the Delaware River to meet fishable water quality standards. The objectives of this research are to estimate the costs of investments to reduce pollutant loads and restore the Delaware River to meet more protective year-round fishable dissolved oxygen criteria in accordance with the Delaware River Basin Commission, Environmental Protection Agency, and state water quality standards.

\section{Methods}

With the following research, we estimate the modern costs of the nitrogen pollutant load reductions necessary to increase dissolved oxygen from the current criterion $(3.5 \mathrm{mg} / \mathrm{L})$ to a future, more stringent water quality standard $(5.0 \mathrm{mg} / \mathrm{L})$ in the Delaware River. To estimate the most cost-effective combination of nitrogen load reductions, we (1) quantified nitrogen loads in the Delaware Basin from atmospheric, urban/suburban, wastewater, and agricultural sources and estimated the pollutant load reductions needed to improve dissolved oxygen in the Delaware River from the current $3.5 \mathrm{mg} / \mathrm{L}$ to a future, more protective standard; (2) estimated the costs of nitrogen load reductions to improve the dissolved oxygen levels in the tidal Delaware River for various best management practice scenarios; and (3) constructed marginal abatement cost curves to define the annual least costs to raise the dissolved oxygen levels to more stringent fishable criteria.

Nitrogen Loads: We estimated annual nitrogen loads in the Delaware Basin in Delaware, New Jersey, New York, and Pennsylvania using the USGS SPAtially Referenced Regressions on Watershed (SPARROW) model [40]. The SPARROW model has been calibrated by the USGS to estimate nitrogen loads for the base year 2002 from point sources (wastewater discharges) and nonpoint sources (atmospheric deposition, agriculture fertilizer/manure, and urban/suburban land) and accounts for watershed characteristics such as precipitation, temperature, soil permeability, stream density, flow rate, velocity, and lake/reservoir hydraulics [41]. The USGS SPARROW model simulates nitrogen removal based on hydrological processes such as denitrification, particulate settling, and water velocity [42]. SPARROW is a nonlinear least squares regression model where the mean annual $\mathrm{N}$ load, as the dependent variable, is weighted by land-to-water movement, instream transport, and assimilation of nitrogen as the explanatory variable (Table 3). Since the USGS SPARROW model calibrates the nitrogen load estimates with EPA STORET water quality monitoring data, the model is well correlated as coefficients of determination $\left(\mathrm{r}^{2}\right)$ are 0.83 for yield and 0.97 for load, which explains $83 \%$ to $97 \%$ of the variance between the predictive model and observed water quality data.

Table 3. Mid-Atlantic SPAtially Referenced Regressions on Watershed (SPARROW) model coefficients [40].

\begin{tabular}{|c|c|c|}
\hline Parameter & Coefficient Unit & Model Coefficient \\
\hline \multicolumn{3}{|l|}{ Nitrogen Sources } \\
\hline Developed land $\left(\mathrm{km}^{2}\right)$ & $\mathrm{kg} / \mathrm{km}^{2} /$ year & 1422 \\
\hline Wastewater discharge (kg/year) & & 1.16 \\
\hline Fertilizer and fixation from agriculture in corn, soybeans, alfalfa (kg/year) & & 0.310 \\
\hline Fertilizer to agriculture in other crops (kg/year) & & 0.186 \\
\hline Manure from livestock ( $\mathrm{kg} /$ year $)$ & & 0.090 \\
\hline \multicolumn{3}{|l|}{ Land to Water Delivery } \\
\hline Mean annual temperature & $\ln \operatorname{deg} C$ & -0.864 \\
\hline Average overland flow distance to stream $(\mathrm{km})$ & $\mathrm{km}^{-1}$ & -0.190 \\
\hline In ratio of nitrate to inorganic $\mathrm{N}$ wet deposition & & 2.56 \\
\hline \multicolumn{3}{|l|}{ Aquatic Decay } \\
\hline Time of travel in stream reach where mean discharge $<2.83 \mathrm{~m}^{3} / \mathrm{s}$ (days) & per day & 0.224 \\
\hline \multicolumn{3}{|l|}{ Statistics } \\
\hline Root Mean Square Error (RSME) & & 0.35 \\
\hline$r^{2}$ load & & 0.97 \\
\hline$r^{2}$ yield & & 0.83 \\
\hline
\end{tabular}


Nitrogen Load Reduction Costs: We estimated the $\mathrm{N}$ load reductions needed to improve water quality to meet a future $5.0 \mathrm{mg} / \mathrm{L}$ dissolved oxygen standard in the Delaware River between Philadelphia and Wilmington. We examined the EPA Water Quality Analysis Simulation Program (WASP), USGS Hydrological Simulation Program-Fortran (HSPF), and Generalized Watershed Loading Function (GWLF) to estimate Total Maximum Daily Load (TMDL) pollutant load reductions in the lower Delaware Basin [43]. These hydrodynamic models suggest "better-than-secondary" treatment is needed to meet a more stringent dissolved oxygen water quality standard of $5 \mathrm{mg} / \mathrm{L}$ in the Delaware River at Philadelphia.

We reviewed a survey of 15 TMDL models by Scatena et al. [44] in the lower Delaware River that suggests that achieving a dissolved oxygen target of $5.0 \mathrm{mg} / \mathrm{L}$ would require a $32 \%$ (median) reduction in nitrogen loading to water bodies, within a range from $20 \%$ (25th percentile) to $48 \%$ ( 75 th percentile) reduction (Figure 5). Similarly, the Brandywine-Christina watershed TMDL model estimated that a $38 \%$ reduction in nitrogen loads is needed to meet a dissolved oxygen water quality criterion of $5 \mathrm{mg} / \mathrm{L}$ in the watershed that contributes $8 \%$ of the $\mathrm{N}$ load to the Delaware Estuary [45].

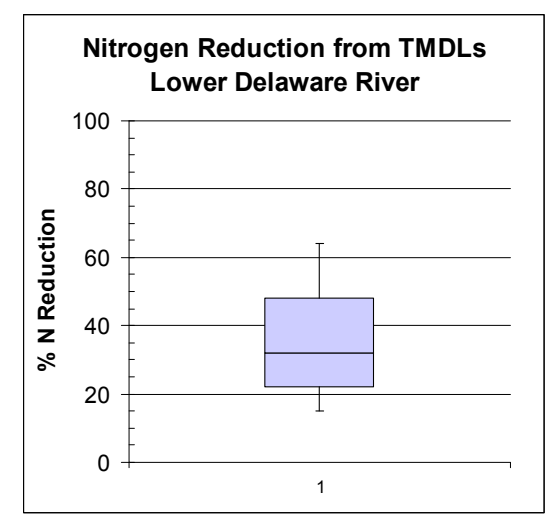

Figure 5. Nitrogen load reductions from Total Maximum Daily Load (TMDL) models for the lower Delaware River [44].

Best Management Practice (BMP) Installation Costs: We derived the unit costs of $\mathrm{N}$ load reductions ( $\$ / \mathrm{lb} \mathrm{N}$ reduced) for point source wastewater treatment BMPs and nonpoint source BMPs such as atmospheric controls (vehicle exhaust and industrial plant scrubbers), urban stormwater retrofitting, stream restoration, wetlands, and agricultural practices such as no till, cover crops, forest buffers, and animal waste management (Table 4).

Table 4. Nitrogen reduction best management practices.

\begin{tabular}{cc}
\hline Nitrogen Source & Best Management Practice (BMP) \\
\hline Wastewater Treatment Plant & Nutrient Reduction Technology \\
\hline Atmospheric Deposition & Motor vehicle exhaust controls \\
& Power/industrial plant scrubbers \\
\hline Ag Nutrient Management Plans \\
Conservation Tillage \\
Cover Crops \\
Diversions \\
Forest Buffers \\
Grass Buffers \\
Terraces \\
\hline Urban/Suburban Stormwater & Wet Detention Pond \\
& Grass Swale \\
& Infiltration Basin \\
& Septic System Replacement \\
& Stormwater Wetland \\
& Vegetated Filter Strip \\
\hline
\end{tabular}


We calculated the costs to reduce nitrogen loads by $20 \%$ (25th percentile), by $32 \%$ (median), and by $48 \%$ (75th percentile) to meet a more stringent DRBC dissolved oxygen standard by multiplying $\mathrm{N}$ load reduction rates $(\mathrm{kg} /$ year) by the unit cost $(\$ / \mathrm{kg})$ (in 2010 dollars) for atmospheric NOX reduction, wastewater treatment, agriculture conservation, and urban/suburban BMPs. The combined Total Maximum Daily Load (TMDL) models for the Delaware River required nitrogen load reductions of $32 \%$ (median) within a range of $20 \%$ (25th percentile) and $48 \%$ ( 75 th percentile). Using benefit (value) transfer principles, we reviewed the literature [46-49] and translated nitrogen load reduction costs $(\$ / \mathrm{kg})$ from nearby watersheds (such as the Chesapeake Bay) to the Delaware River watershed since the adjacent watersheds share similar climate, soils, topography, physiography, and hydrogeology.

Total Nitrogen Load Reduction Costs: We estimated the costs to reduce nitrogen loads by the median $32 \%$ by maximizing load reductions from least cost agriculture and wastewater sources for the following five options. We estimated the nitrogen load reduction costs by multiplying the necessary nitrogen load reduction from the SPARROW model ( $\mathrm{kg} \mathrm{N} /$ year) by the nitrogen load reduction costs $(\$ / \mathrm{kg} \mathrm{N})$. Option 1 would reduce nitrogen loads equally by the median $32 \%$ from all sources (agriculture, wastewater, atmospheric, and urban/suburban stormwater). Option 2 would reduce nitrogen loads from agriculture by $32 \%$, wastewater by $47 \%$, atmospheric deposition by $5 \%$, and urban/suburban stormwater by $5 \%$. Option 3 would reduce nitrogen loads from agriculture by $60 \%$, wastewater by $29 \%$, atmospheric deposition by $5 \%$, and urban/suburban stormwater by $5 \%$. Option 4 would reduce nitrogen loads from agriculture by $75 \%$, wastewater by $20 \%$, atmospheric deposition by $5 \%$, and urban/suburban stormwater by $5 \%$. Options 5 would reduce nitrogen loads from agriculture by $90 \%$, wastewater by $10 \%$, atmospheric deposition by $5 \%$, and urban/suburban stormwater by $5 \%$.

Marginal Abatement Costs: We constructed nitrogen marginal abatement cost (MAC) curves to determine the most cost-effective $\mathrm{N}$ load reductions to improve water quality by raising dissolved oxygen in the Delaware River to more stringent fishable criteria. The marginal cost curves show the change in cost compared with the change in reduced pollutant loads. The MAC curve is constructed by plotting pollutant load reductions by percentage or in $\mathrm{kg} /$ year ( $\mathrm{lb} /$ year) for the practices and by the annual costs of these measures. The MAC curves are constructed by plotting $\mathrm{N}$ load reduction costs (\$/year) on the horizontal axis and 25th, 50th (median), and 75th percentile $\mathrm{N}$ load reductions on the vertical axis. Typical marginal abatement cost curves [50] depict relatively inexpensive measures on the left and more expensive measures to the right (Figure 6).

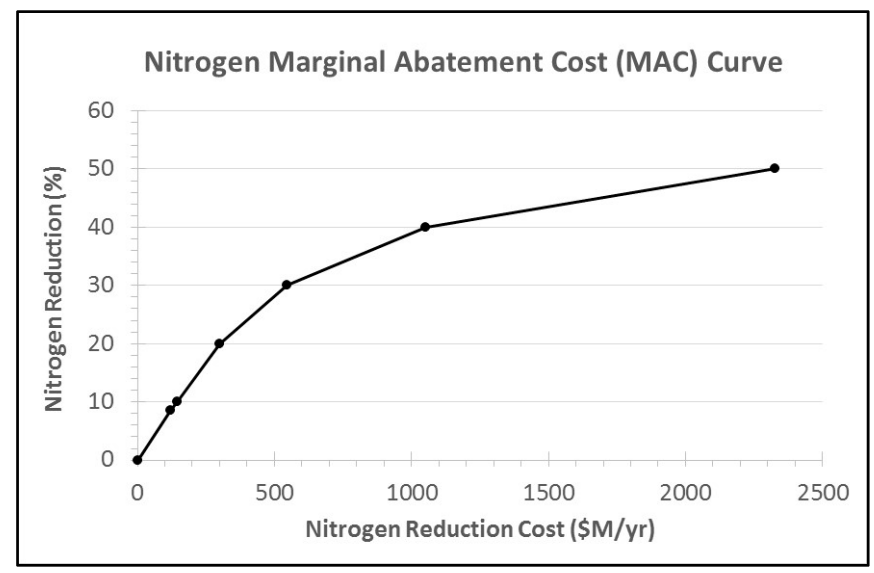

Figure 6. Nitrogen marginal abatement cost (MAC) curve in the Netherlands [50].

\section{Results}

Results from our use of the USGS SPARROW model indicates that the highest nitrogen loads in the Delaware River watershed are delivered in the Schuylkill River and Brandywine-Christina watersheds in southeastern Pennsylvania (Figure 7). The Delaware River receives the second-highest 
nitrogen load of any river basin along the Atlantic Coast of the USA (Table 5). The SPARROW model utilizes land cover data to predict the nitrogen loads from urban/suburban and agricultural runoff. Our GIS analysis utilizing 2006 NOAA Coastal Services Center (CSC) land use/land cover data indicates that the Delaware River Basin was covered by 63\% forest/wetlands, $20 \%$ agriculture, and $17 \%$ urban/suburban land. Pennsylvania covers 51\%, New Jersey and New York each cover 21\%, and Delaware covers $8 \%$ of the Delaware River Basin. The spatial distribution and fragmentation of land cover types affect pollutant loads to waterways; for example, farmed areas next to streams will deliver a higher nitrogen yield that can be filtered by riparian forested buffer areas. Based on the delivery fraction of nitrogen (proportion of $\mathrm{N}$ load delivered to the outlet), BMPs implemented in watersheds closest to the Delaware Estuary provide the most immediate improvements in water quality.

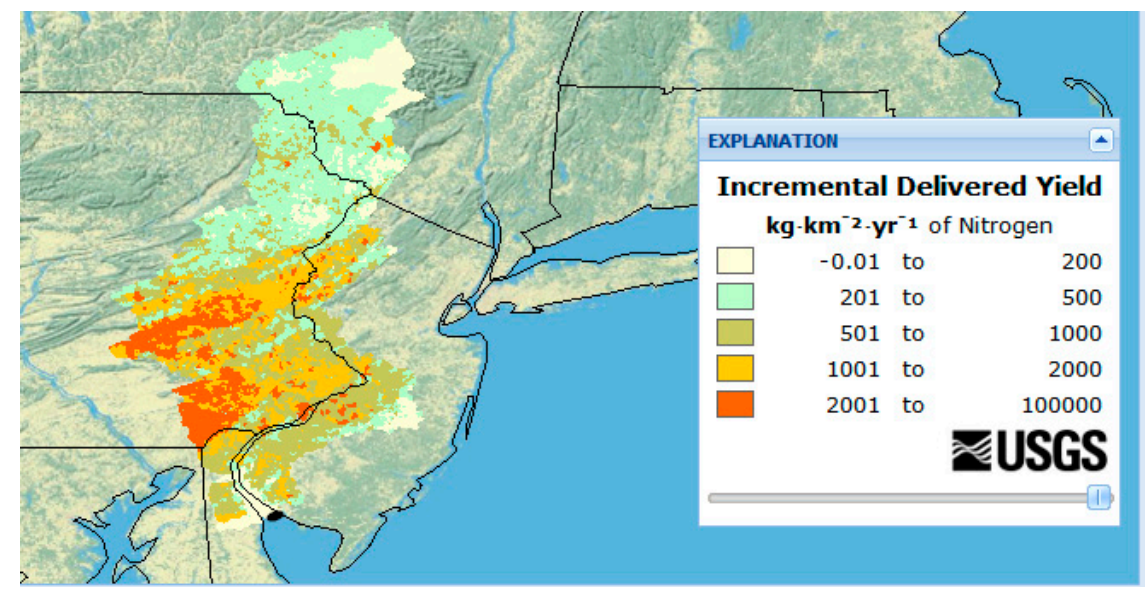

Figure 7. Incremental delivered nitrogen yield to Delaware Basin from SPARROW model.

Table 5. Nitrogen loads in Atlantic Coast river basins from USGS SPARROW model.

\begin{tabular}{cccc}
\hline River Basin & Drainage Area $\left.\mathbf{( k m}^{\mathbf{2}}\right)$ & $\begin{array}{c}\text { Nitrogen Load } \\
\mathbf{( k g / Y e a r )}\end{array}$ & $\begin{array}{c}\text { Unit N Load } \\
\mathbf{( k g / k m} / \text { Year) }\end{array}$ \\
\hline Susquehanna & 71,199 & $66,320,320$ & 931 \\
Delaware & 30,611 & $45,876,700$ & 1499 \\
Potomac & 37,964 & $40,593,956$ & 1069 \\
Hudson & 34,610 & $26,069,588$ & 753 \\
James & 26,778 & $15,873,656$ & 593 \\
Connecticut & 29,166 & $15,650,288$ & 537 \\
\hline
\end{tabular}

In the Delaware Basin, our analysis using the SPARROW model indicates that almost half $(46 \%)$ of the nitrogen flows from wastewater discharges and a third (29\%) emanates from agriculture fertilizer/manure runoff (Figure 8). Urban/suburban stormwater from the cities and suburbs delivers just over $10 \%$ of the $\mathrm{N}$ load. The airshed of the Delaware River is 10 times larger than its watershed and atmospheric deposition from industries and vehicles contributes $12 \%$ of the nitrogen to the estuary. Together, Pennsylvania and New Jersey discharge over $90 \%$ of the nitrogen to the Delaware Basin with half from wastewater discharges and a quarter to a third from agriculture. New York and Delaware contribute $4 \%$ and $3 \%$ of the nitrogen, respectively.

From the USGS SPARROW model, we found that three watersheds-the Delaware River at Trenton, Schuylkill River, and above-Philadelphia tributaries-deliver $80 \%$ of the nitrogen load to the estuary. Above Trenton, the Lehigh River contributes 9\% of the $\mathrm{N}$ load to the Delaware River. Below Philadelphia, the Brandywine-Christina, Delaware River above Wilmington, and Delaware Estuary at Prime Hook watersheds contribute 7\%, 8\%, and 3\% of the $\mathrm{N}$ loads, respectively. Wastewater discharges are the predominant sources of $\mathrm{N}$ in the Delaware River above Philadelphia (82\%), Schuylkill 
(46\%), and above-Wilmington (68\%) watersheds. Agriculture is the primary N source in the Delaware River at the Trenton (34\%), Brandywine-Christina (77\%), and Delaware Bay at Prime Hook (72\%) watersheds and the second-highest N source in the Schuylkill watershed (35\%).

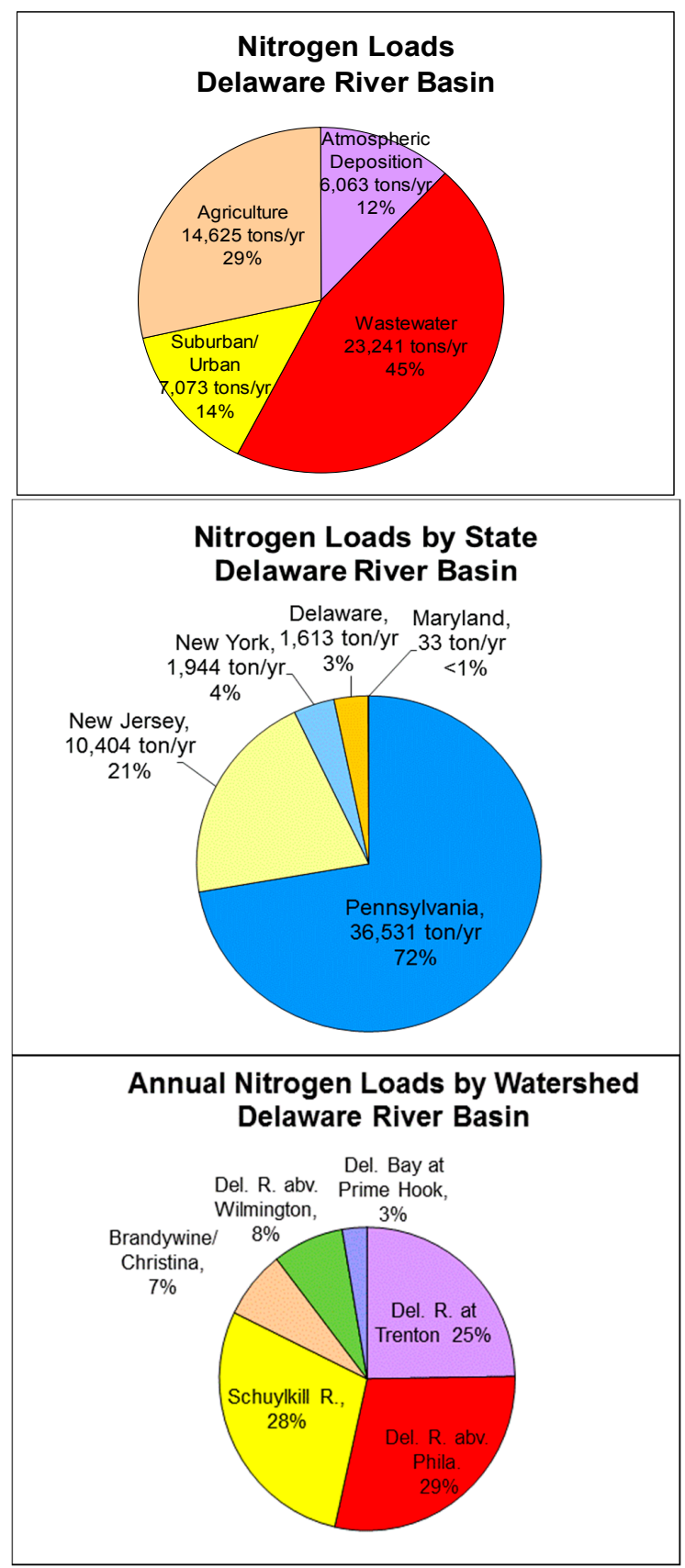

Figure 8. Annual nitrogen loads in the Delaware Basin from USGS SPARROW Model.

We observed that nitrogen loads at USGS gages compare within 25-30\% ( \pm ) of modeled loads from SPARROW [51]. The observed annual $\mathrm{N}$ load at Delaware River at Trenton is $14.2 \mathrm{million} \mathrm{kg}$ (31.2 million $\mathrm{lb}$ ) compared to 11.4 million $\mathrm{kg}$ (25.1 million lb) from SPARROW. Along the Schuylkill, the observed annual $\mathrm{N}$ load is 9.4 million $\mathrm{kg}$ (20.8 million $\mathrm{lb}$ ) versus 13.1 million $\mathrm{kg}$ (28.9 million $\mathrm{lb}$ ) from the SPARROW model. The variance may be due to the difference between loads modeled during the SPARROW base year of 2002 and the period of recording at each of the stream monitoring stations. Also, the observed data would include nitrogen loads delivered by groundwater to the streams and the 
SPARROW model may under-report groundwater sources of nitrogen. Given the variance of $25-30 \%$ $( \pm)$ between the observed and modeled nitrogen loads in the Delaware River Basin, we expect the costs of pollutant load reduction programs in the watershed will vary by a similar amount.

Our synthesis of the literature [5,46-49] reveals that nitrogen reduction costs vary from $\$ 2.64-\$ 24.20 / \mathrm{kg} \mathrm{N}(\$ 1.20-\$ 11.0 \$ / \mathrm{lb} \mathrm{N})$ for agricultural conservation, $\$ 18.83-\$ 174 / \mathrm{kg} \mathrm{N}$ (\$8.56-\$79.00\$/lb N) for wastewater treatment, \$165-\$639/kg N (\$75.00-\$132.00 \$/lb N) for airborne emissions controls, and $\$ 198-\$ 1100 / \mathrm{kg} \mathrm{N}(\$ 90.00-\$ 500.00 \$ / \mathrm{lb} \mathrm{N})$ for urban/suburban stormwater retrofit BMPs (Table 6). Wastewater treatment $\mathrm{N}$ load reduction costs vary from $\$ 18.83-\$ 60.83 / \mathrm{kg}$ $\mathrm{N}(\$ 8.56-\$ 27.65 \$ / \mathrm{lb} \mathrm{N})$ in the Chesapeake Bay watershed to $\$ 38.06 / \mathrm{kg} \mathrm{N}(\$ 17.30 \$ / \mathrm{lb} \mathrm{N})$ in the Connecticut River Basin and \$139.00-\$174.00/kg N (\$63.00-\$79.00 \$/lb N) in Maine and New Hampshire. Airborne deposition nitrogen load reduction costs in the Chesapeake Bay range from $\$ 165 / \mathrm{kg}$ N (\$75.00/lb N) for Clean Air Act programs to $\$ 639 / \mathrm{kg} \mathrm{N}(\$ 132.00 / \mathrm{lb} \mathrm{N})$ for low-emission vehicle programs. Urban stormwater retrofitting is a more expensive option with costs that range from \$198-\$1100/kg N (\$90-\$500/lb N) reduced.

Our survey of the literature indicates that agricultural conservation practices reduce $\mathrm{N}$ loads by $40 \%$ for grass buffers to $90 \%$ for cover crops at unit costs that range from $\$ 2.64 / \mathrm{kg} \mathrm{N}(\$ 1.20 / \mathrm{lb} \mathrm{N})$ for forest buffers to $\$ 22.24 / \mathrm{kg} \mathrm{N}(\$ 10.11 / \mathrm{lb} \mathrm{N})$ for cover crops. Agricultural nutrient management plans reduce $\mathrm{N}$ by $20 \%$ at a cost of $\$ 4.41 \$ / \mathrm{lb} \mathrm{N}$. No-till cropping can reduce $\mathrm{N}$ by $55 \%$ at a cost of $\$ 7.04 / \mathrm{kg} \mathrm{N}(\$ 3.20 / \mathrm{lb} \mathrm{N})$ reduced. Forest buffers remove $50 \%$ of $\mathrm{N}$ at $\$ 2.64$ to $\$ 14.94 / \mathrm{kg} \mathrm{N}(\$ 1.20$ to $\$ 6.79 \$ / \mathrm{lb} \mathrm{N})$. Grass buffers remove $40 \%$ of $\mathrm{N}$ at $\$ 3.45$ to $\$ 14.87 / \mathrm{kg} \mathrm{N}(\$ 1.57$ to $6.76 \$ / \mathrm{lb} \mathrm{N})$.

We calculated the costs to reduce nitrogen loads by $20 \%$ (25th percentile), $32 \%$ (median), and $48 \%$ (75th percentile) to meet a more stringent DRBC dissolved oxygen standard by multiplying $\mathrm{N}$ load reduction rates $(\mathrm{kg} /$ year) by the unit cost $(\$ / \mathrm{kg})$ (in 2010 dollars) for atmospheric NOX reduction $\$ 165 / \mathrm{kg}(\$ 75.00 / \mathrm{lb})$, wastewater treatment $\$ 61.60 / \mathrm{kg}(\$ 28.00 / \mathrm{lb})$, agriculture conservation $\$ 11.00 / \mathrm{kg}$ (\$5.00/lb), and urban/suburban $\$ 440 / \mathrm{kg}$ (\$200/lb) BMPs (Figure 9).

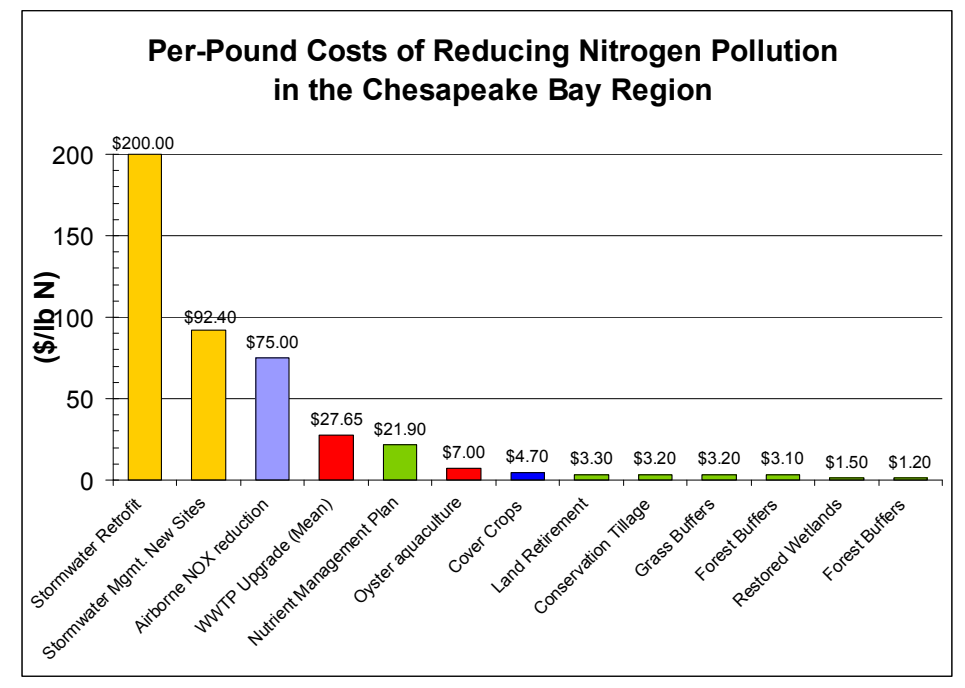

Figure 9. Costs (in 2010 dollars) to reduce nitrogen pollution in the Chesapeake Bay region [5,46].

Table 6. Nitrogen reduction costs by source [5,46-49].

\begin{tabular}{|c|c|c|c|c|c|c|c|c|}
\hline \multirow{2}{*}{ Location } & \multicolumn{2}{|c|}{ Atmospheric Deposition } & \multicolumn{2}{|c|}{ Wastewater Treatment } & \multicolumn{2}{|c|}{ Urban/Sub. Stormwater } & \multicolumn{2}{|c|}{ Agriculture Conservation } \\
\hline & $(\$ / 1 \mathrm{lb} \mathrm{N})$ & $(\$ / k g ~ N)$ & $(\$ / \mathrm{lb} \mathrm{N})$ & $(\$ / k g ~ N)$ & $(\$ / 1 b ~ N)$ & $(\$ / k g ~ N)$ & $(\$ / l b ~ N)$ & $(\$ / k g ~ N)$ \\
\hline Chesapeake Bay & 75 & 165 & 27.65 & 60.83 & $200-500$ & $440-1100$ & $1.20-4.70$ & $2.64-10.34$ \\
\hline New Hampshire & & & $63-79$ & 139-174 & & & & \\
\hline Long Island Sound & & & 17.30 & 38.06 & 137 & 301 & 4.93 & 10.85 \\
\hline Iowa & & & & & 90 & 198 & $2.00-11.00$ & $4.40-24.20$ \\
\hline Chesapeake Bay & & & 8.56 & 18.83 & $>100$ & $>220$ & $1.57-4.41$ & $3.45-9.70$ \\
\hline United States & $75-132$ & $165-639$ & & & & & & \\
\hline Maryland & & & & & $104-210$ & $229-462$ & $1.57-10.11$ & $3.45-22.24$ \\
\hline
\end{tabular}


Under Option 1, we estimate that nitrogen loads must be reduced by 14.7 million $\mathrm{kg}$ /year (32.3 million $\mathrm{lb} /$ year) to achieve $32 \%$ reductions applied equally to all sources (Table 7). Under this uniform load reduction scenario, wastewater $\mathrm{N}$ loads are reduced by 6.8 million $\mathrm{kg} /$ year (14.9 million $\mathrm{lb} /$ year) followed by agriculture by 4.3 million $\mathrm{kg} /$ year $(9.4$ million $\mathrm{lb} /$ year), urban/suburban by 2.0 million $\mathrm{kg}$ /year ( 4.5 million lb/year), and atmospheric by 1.8 million $\mathrm{kg} /$ year (3.9 million $\mathrm{lb} /$ year). The cost to reduce $\mathrm{N}$ loads evenly by 32\% for each source is $\$ 1.66$ billion/year with the largest costs borne by urban/suburban stormwater retrofitting ( $\$ 905$ million/year) with the highest unit cost, followed by wastewater discharge ( $\$ 416$ million/year), atmospheric NOX reduction (\$291 million/year), and agriculture conservation (\$47 million) with the lowest unit cost.

Table 7. Least Cost (in 2010 dollars) by state to reduce nitrogen by the median $32 \%$ in Delaware Basin.

\begin{tabular}{|c|c|c|c|c|c|c|}
\hline State & $\begin{array}{c}\text { Drainage Area } \\
\left(\mathbf{k m}^{2}\right)\end{array}$ & $\begin{array}{c}\text { Nitrogen } \\
\text { Reduction } \\
(32 \%) \\
\text { (M kg/Year) }\end{array}$ & $\begin{array}{c}\text { Atmospheric } \\
\text { Deposition (5\%) } \\
\text { (M kg/Year) }\end{array}$ & $\begin{array}{c}\text { Wastewater } \\
\text { Discharge (10\%) } \\
\text { (M kg/Year) }\end{array}$ & $\begin{array}{c}\text { Urban/Suburban } \\
(5 \%) \\
\text { (M kg/Year) }\end{array}$ & $\begin{array}{c}\text { Agriculture } \\
\text { Conservation } \\
(90 \%) \\
(\mathrm{M} \mathrm{kg} / \text { Year) }\end{array}$ \\
\hline Pennsylvania & 15,506 & 10.91 & 0.18 & 1.55 & 0.23 & 8.95 \\
\hline New Jersey & 6374 & 2.73 & 0.05 & 0.50 & 0.05 & 2.14 \\
\hline New York & 6358 & 0.45 & 0.05 & 0.01 & 0.01 & 0.36 \\
\hline Delaware & 2352 & 0.55 & 0.00 & 0.05 & 0.01 & 0.45 \\
\hline Maryland & 21 & 0.02 & 0.00 & 0.00 & 0.00 & 0.00 \\
\hline Del. Basin & 30,611 & 14.68 & 0.27 & 2.09 & 0.32 & 12.00 \\
\hline State & $\begin{array}{c}\text { Drainage Area } \\
\left(\mathbf{k m}^{2}\right)\end{array}$ & $\begin{array}{l}\text { Nitrogen } \\
\text { Reduction Cost } \\
\text { (\$M/Year) }\end{array}$ & $\begin{array}{c}\text { Atmospheric } \\
\text { Deposition } \\
\text { (\$165/kg N) } \\
\text { (\$M/Year) }\end{array}$ & $\begin{array}{l}\text { Wastewater } \\
\text { Discharge } \\
\text { (\$62/kg N) } \\
\text { (\$M/Year) }\end{array}$ & $\begin{array}{c}\text { Urban/Suburban } \\
\text { (\$440/kg N) } \\
\text { (\$M/Year) }\end{array}$ & $\begin{array}{c}\text { Agriculture } \\
\text { Conservation } \\
(\$ 11 / \text { kg N) } \\
(\$ M / \text { Year) }\end{array}$ \\
\hline Pennsylvania & 15,506 & 322 & 27 & 94 & 102 & 99 \\
\hline New Jersey & 6374 & 87 & 8 & 31 & 25 & 23 \\
\hline New York & 6358 & 19 & 8 & 0.6 & 6 & 4 \\
\hline Delaware & 2352 & 16 & 1 & 3 & 6 & 5 \\
\hline Maryland & 21 & 0.3 & 0.02 & 0 & 0.08 & 0.2 \\
\hline Del. Basin & 30,611 & 449 & 45 & 130 & 142 & 132 \\
\hline
\end{tabular}

According to Option 1, to reduce $\mathrm{N}$ equally by $32 \%$ from all sources, we estimate that annual loads must be reduced by 10.6 million $\mathrm{kg}$ in Pennsylvania for $\$ 1.2$ billion, 3.0 million $\mathrm{kg}$ in New Jersey for $\$ 317$ million, $600,000 \mathrm{~kg}$ in New York for $\$ 95$ million, 500,000 kg in Delaware for $\$ 60$ million, and $11,000 \mathrm{~kg}$ in Maryland for $\$ 700,000$.

Our review of the TMDL models suggest that nitrogen loads should be reduced by a median $32 \%$ within a range of $20 \%$ (25th percentile) to $48 \%$ (75th percentile) to increase dissolved oxygen levels from the current DRBC criterion $(3.5 \mathrm{mg} / \mathrm{L})$ to meet a future standard $(5.0 \mathrm{mg} / \mathrm{L})$ in the Delaware River. By maximizing least cost agricultural and wastewater BMP options and minimizing higher cost airborne emissions and urban stormwater BMPs (Figure 10), annual costs to reduce $\mathrm{N}$ loads by $32 \%$ in the Delaware Basin are cut from $\$ 1.66$ billion for Option 1 (reduce loads evenly for all sources) to $\$ 845$ million for Option 2 (reduce Ag N by 32\%), \$652 million for Option 3 (reduce Ag N by 60\%), $\$ 552$ million for Option 4 (reduce Ag N by 75\%), and $\$ 449$ million for Option 5 (reduce Ag N by $90 \%$ ).

We found that the least cost (Option 5) would reduce $\mathrm{N}$ loads by the median $32 \%$ or 14.5 million $\mathrm{kg}$ /year (32 million $\mathrm{lb} /$ year) by reducing atmospheric NOX by $5 \%$, wastewater $\mathrm{N}$ by $10 \%$, urban/suburban $\mathrm{N}$ by $5 \%$, and agricultural $\mathrm{N}$ by $90 \%$. Annual costs range from $\$ 334$, $\$ 449$, and $\$ 904$ million to reduce $\mathrm{N}$ loads by $20 \%$ (25th percentile), $32 \%$ (median), and $48 \%$ (75th percentile), respectively. 


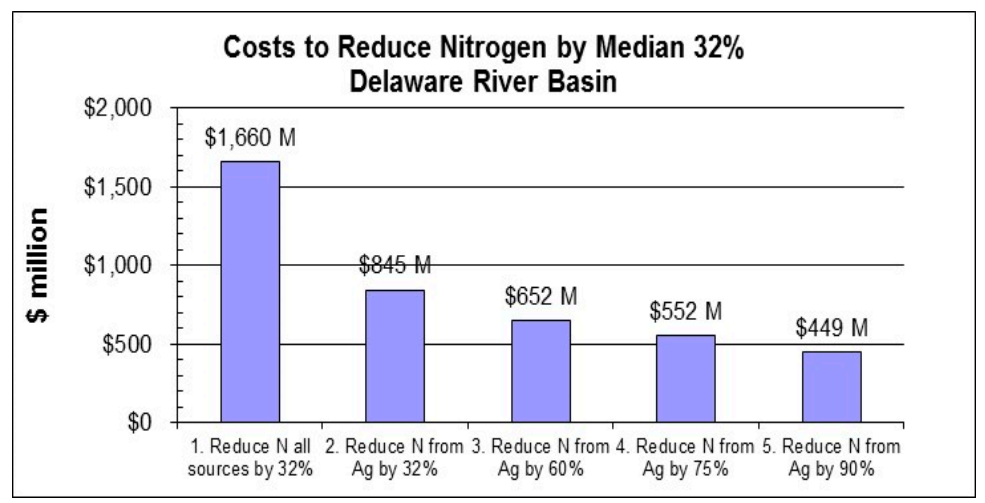

Figure 10. Costs (in 2010 dollars) to reduce nitrogen loads by $32 \%$ in the Delaware Basin.

According to Option 5, we conclude that the annual least cost to reduce $\mathrm{N}$ loads by $32 \%$ in the Delaware Basin is \$449 million, including \$141 million for urban/suburban retrofitting, \$132 million for agriculture conservation, $\$ 130$ million for wastewater treatment, and $\$ 45$ million for atmospheric NOX reduction (Figure 11). Covering half of the Basin, Pennsylvania's annual share is $\$ 322$ million or $72 \%$ of the N load reduction cost (Figure 12). New Jersey would bear $\$ 87$ million or $19 \%$ of the cost. New York State would contribute $\$ 19$ million or $4 \%$ of the $\mathrm{N}$ reduction cost. Delaware would assume $\$ 16$ million or $4 \%$ of the cost. Maryland's share would be $\$ 337,000$.

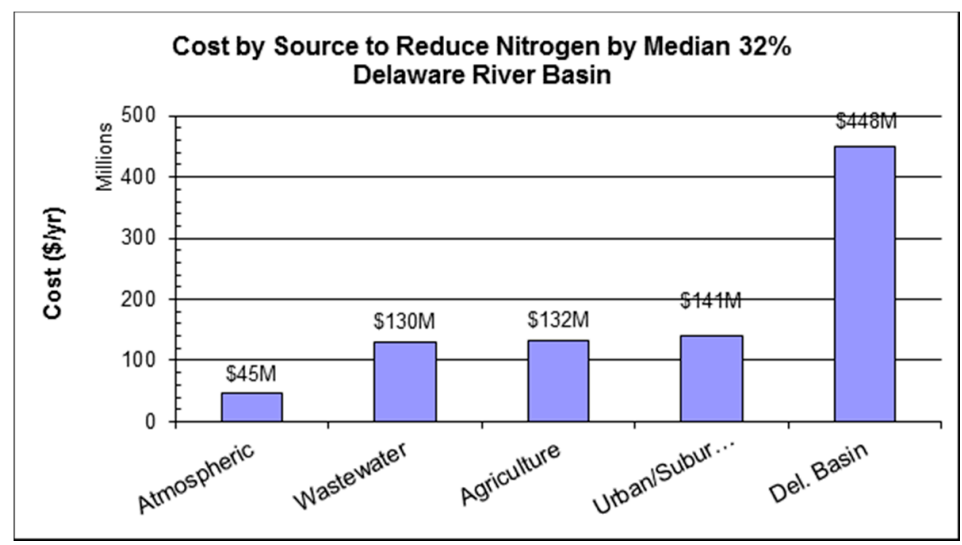

Figure 11. Least cost (in 2010 dollars) by source to reduce nitrogen loads by $32 \%$ in Delaware Basin.

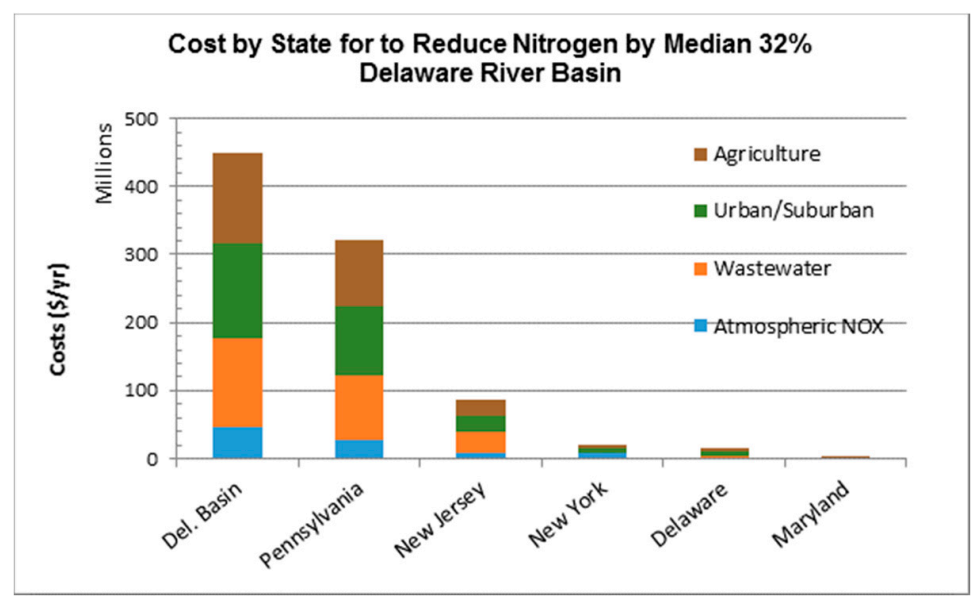

Figure 12. Least cost (in 2010 dollars) by state to reduce nitrogen loads by $32 \%$ in Delaware Basin. 
On a watershed basis, we estimate that the Delaware River at Trenton contributes $25 \%$ of the nitrogen load, predominately from agricultural sources, for $\$ 132$ million or $30 \%$ of the total cost (Figure 13 and Table 8). The Schuylkill contributes $30 \%$ of the $\mathrm{N}$ load, mostly from wastewater and agricultural sources, at a cost of $\$ 124$ million or $28 \%$ of the total cost. The tributaries between Philadelphia and Trenton contribute $29 \%$ of the $\mathrm{N}$ load, mostly from wastewater, with a cost of $\$ 104$ million or $24 \%$ of the total. The Brandywine-Christina watershed, where over three-quarters of the nitrogen flows from agriculture, would cost $\$ 37$ million ( $8 \%$ of the $\mathrm{N}$ load reduction cost). The watersheds between Wilmington and Philadelphia would require $\$ 32$ million or $7 \%$ of the total cost to reduce mostly wastewater $\mathrm{N}$ loads. The Delaware Bay watershed between Prime Hook and Wilmington would cost \$13 million to reduce the mostly agricultural $\mathrm{N}$ loads from the Coastal Plain streams on either side of the bay.

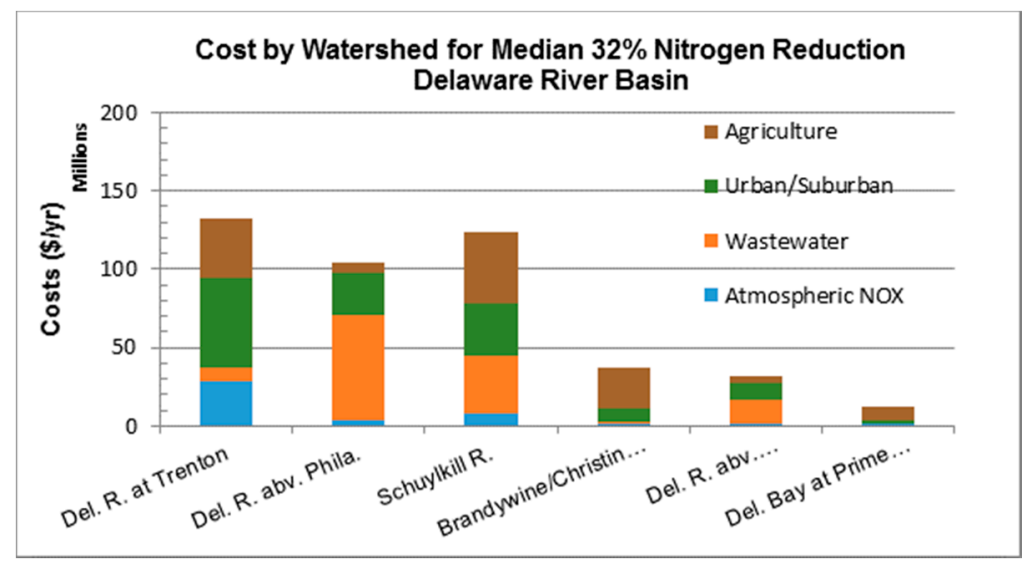

Figure 13. Least cost by watershed to reduce nitrogen loads by $32 \%$ in the Delaware Basin.

Table 8. Least cost by watershed to reduce nitrogen by the median $32 \%$ in the Delaware Basin.

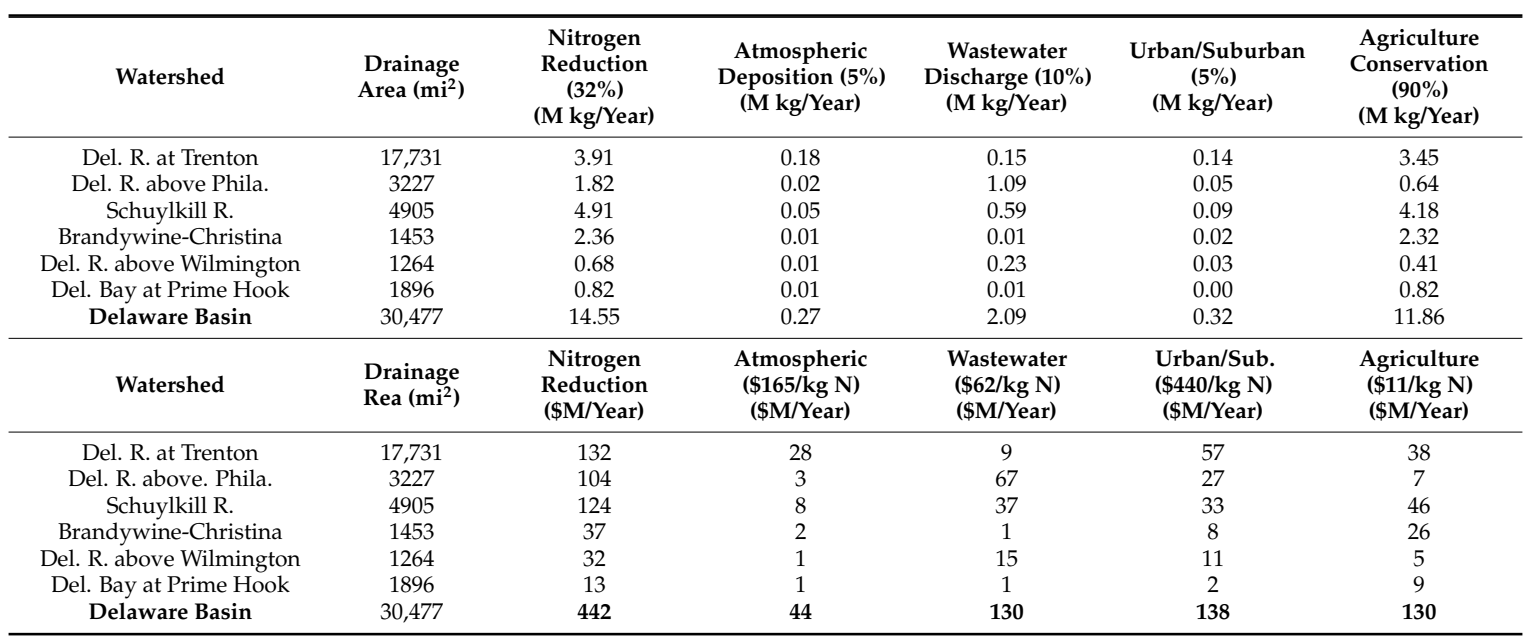

We constructed marginal abatement cost curves (Figures 14 and 15) that illustrate the least costs to reduce nitrogen loads by the median $32 \%$ within a range of $20 \%$ (25th percentile) to $48 \%$ (75th percentile). The nitrogen MAC curve indicates that, by prioritizing investments in agriculture conservation and some wastewater treatment projects first, $90 \%$ of the nitrogen (13.6 million $\mathrm{kg} \mathrm{N} /$ year) (30 million $\mathrm{lb} \mathrm{N} /$ year) can be removed for just 35\% (\$160 million) of the \$449 million total cost. The remaining 0.9 million $\mathrm{kg} \mathrm{N} /$ year (2 million $\mathrm{lb} \mathrm{N} /$ year) or $10 \%$ of the $\mathrm{N}$ load reduction will require $65 \%$ (\$290 million/year) of the total cost to implement the remaining wastewater treatment followed by more expensive atmospheric deposition, and urban/suburban projects. The marginal abatement cost 
(MAC) curves define the most cost-effective combination of nitrogen reduction strategies to improve dissolved oxygen to a future DRBC standard to provide year-round propagation of anadromous fish. The least cost agriculture and wastewater treatment reductions would be implemented first in priority watersheds, followed by higher cost atmospheric deposition and urban suburban runoff controls. After the less costly agricultural and wastewater BMPs are implemented, nitrogen reduction in the Delaware Basin becomes incrementally less cost-effective after $30 \% \mathrm{~N}$ reduction as the slope of the cost curve flattens. Increasingly higher investments in costly atmospheric and urban/suburban controls provide a diminishing rate of return in terms of pollutant removal efficiency per dollar spent.

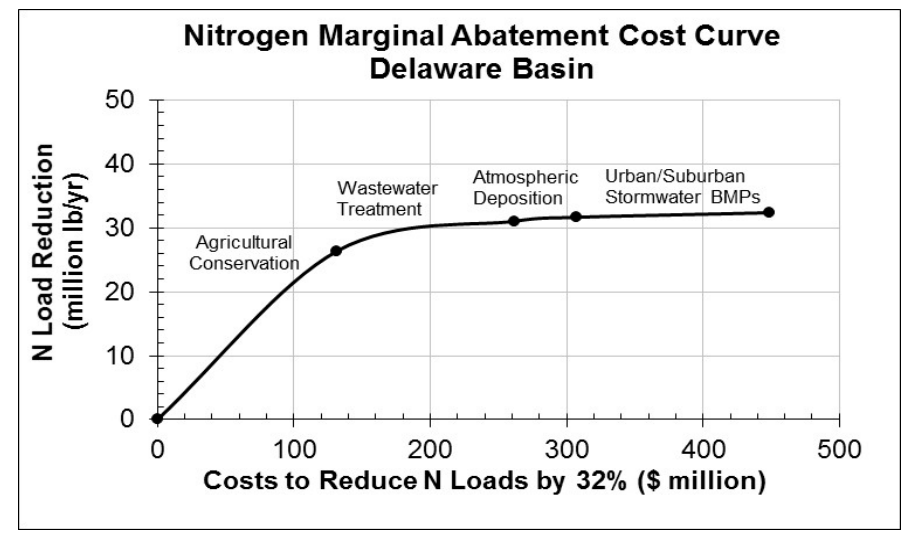

Figure 14. Nitrogen marginal abatement cost curves in the Delaware Basin.

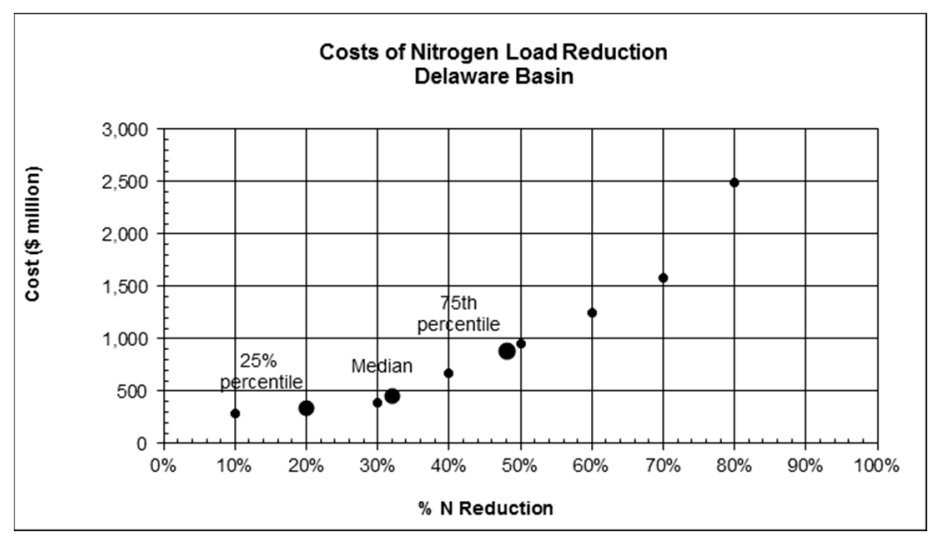

Figure 15. Nitrogen reduction cost curve for the Delaware Basin (in 2010 dollars).

We compared the 1966 Delaware River economic valuation study to our 2017 modern study. Adjusting to 2010 dollars and starting from a base dissolved oxygen level of $3 \mathrm{mg} / \mathrm{L}$, our review of the 1966 Delaware Estuary economic study indicates that the annual costs to improve water quality ranged from \$58-\$87 million to achieve summer dissolved oxygen of $4.0 \mathrm{mg} / \mathrm{L}$ to $\$ 180-\$ 209$ million to reach $4.5 \mathrm{mg} / \mathrm{L}$ (Table 9). These estimates from the 50-year old economic study compare with our 21st century least cost (Option 5), which indicates that annual costs of $\$ 50$ million would need to be invested to reduce pollutant loads to improve dissolved oxygen levels to $4.0 \mathrm{mg} / \mathrm{L}, \$ 150$ million would be needed to reach a dissolved oxygen level of $4.5 \mathrm{mg} / \mathrm{L}$, and $\$ 449$ million would be needed to reach a dissolved oxygen level of $5.0 \mathrm{mg} / \mathrm{L}$ in the Delaware River.

While the costs of the 1966 study and our 2017 economic study compare favorably, the methods and approaches differ. The 1966 economic study explored only the costs of point source load reductions (wastewater treatment plant upgrades) of nitrogen whereas our 2017 analysis estimated the costs of point sources such as wastewater treatment plants and nonpoint sources (airborne deposition, 
stormwater, and agriculture) sources of nitrogen. Also, the 1966 study estimated costs of nitrogen load reduction starting from a baseline of very poor water quality (dissolved oxygen levels at or near zero) and the 2017 study estimates costs of load reduction starting at a baseline of moderate water quality (dissolved oxygen level at $3.5 \mathrm{mg} / \mathrm{L}$ ) in the Delaware River.

Table 9. Comparison of costs to meet water quality criteria along the Delaware River.

\begin{tabular}{cccc}
\hline \multirow{2}{*}{ Objective } & \multirow{2}{*}{ Dissolved Oxygen (mg/L) } & \multicolumn{2}{c}{ Costs (in 2010 Dollars) (\$M/Year) } \\
\cline { 3 - 4 } & & FWPCA $^{\mathbf{1}}$ [32] (1966) & Modern Study (2017) \\
\hline I & 5.0 & & 449 \\
II & 4.5 & $180-209$ & 150 \\
III & 4.0 & $58-87$ & 50 \\
\hline
\end{tabular}

Note: 1 . Adjusted from 1964 dollars to 2010 dollars by 3\% annually based on change in Consumer Price Index.

We point out an important consideration concerning the inverse relationship between dissolved oxygen saturation and water temperature in the Delaware River (Figure 16). The costs of achieving improved water quality in the Delaware River to meet more stringent dissolved oxygen criteria are based on conditions where water temperatures peak near $30^{\circ} \mathrm{C}\left(86^{\circ} \mathrm{F}\right)$, usually in July and August. At $30{ }^{\circ} \mathrm{C}$, freshwater dissolved oxygen $100 \%$ saturation is $7.54 \mathrm{mg} / \mathrm{L}$ and dissolved oxygen is $46 \%$ saturated at $3.5 \mathrm{mg} / \mathrm{L}, 53 \%$ saturated at $4.0 \mathrm{mg} / \mathrm{L}, 66 \%$ saturated at $5.0 \mathrm{mg} / \mathrm{L}$, and $80 \%$ saturated at $6.0 \mathrm{mg} / \mathrm{L}$. Should water temperatures in the tidal Delaware River increase by $2{ }^{\circ} \mathrm{C}$ to peak summer levels of $30{ }^{\circ} \mathrm{C}$, based on saturation, dissolved oxygen levels will decline by about $0.2 \mathrm{mg} / \mathrm{L}$ without any decrease in nutrient loading. More research is needed utilizing a new hydrodynamic model to be developed by the DRBC that would explore the influence of water temperature and salinity on dissolved oxygen in the Delaware Estuary.

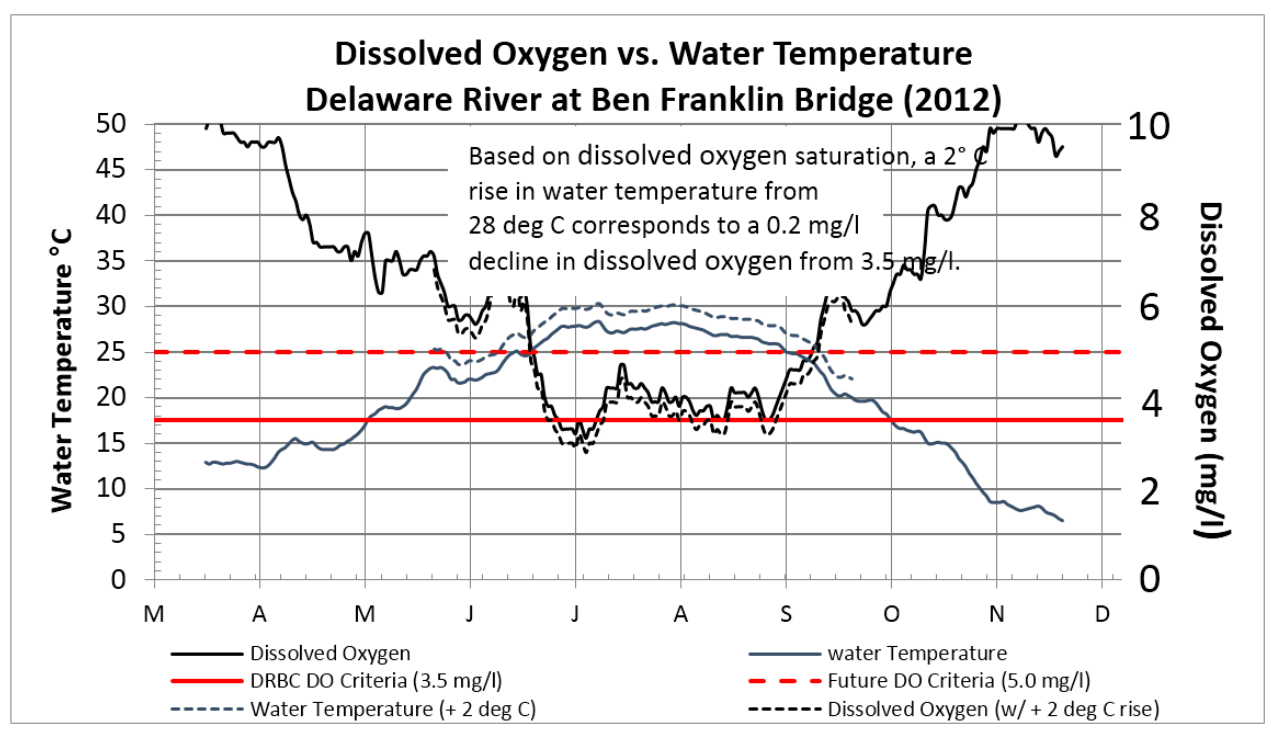

Figure 16. Dissolved oxygen/water temperature along the Delaware River at Ben Franklin Bridge.

Based on the delivery fraction of nitrogen (i.e., fraction of nitrogen load delivered to the outlet), implementation of BMPs in watersheds closest to the Delaware Estuary would provide the most immediate improvements in water quality. The SPARROW model indicates that the delivered yield of nitrogen from watersheds far from the estuary, such as headwaters of the Delaware River in New York State and upper Lehigh and Schuylkill basins, are less likely to influence dissolved oxygen levels in 
the Delaware Estuary. Nitrogen reduction practices should be cost-effectively invested in watersheds that deliver the highest yield of nitrogen and are close to the estuary.

Groundwater can contribute significant nitrogen and phosphorus loads to surface waters. For instance, half of the nonpoint source $\mathrm{N}$ load to the Chesapeake Bay flows through groundwater and the other half flows to the bay via surface runoff [52]. Depending on soil permeability, it could take years for nutrients such as $\mathrm{N}$ and $\mathrm{P}$ in groundwater to reach the Delaware Estuary from source waters [53]. The implementation of nitrogen source controls for airborne emissions and wastewater treatment would have an immediate effect in improving water quality in the Delaware River, whereas urban, suburban, and agriculture BMPS could take months to years to make an impact on water quality, depending on soils and the physiographic province. The SPARROW model does not account for direct contributions of nitrogen from groundwater; therefore, it is likely that nitrogen loads to the tidal Delaware River are underestimated in this analysis. Additional modeling-particularly geographically resolved hydrodynamic modeling, with explicit inclusion of groundwater transport-is needed to address this quantitatively.

\section{Conclusions}

The Delaware River and its tributaries have made a notable recovery in the half-century since JFK signed the DRBC Compact in 1961, Richard Nixon formed the EPA in 1970, and Congress passed the Federal Clean Water Act Amendments during the 1970s. A first-of-its-kind 1966 benefit-cost analysis conducted by the Federal Water Pollution Control Administration (FWPCA) concluded that it would be cost-effective for the DRBC to fund a multi-million-dollar per year waste load abatement program to raise dissolved oxygen levels to boatable and fishable standards that would, in turn, generate economic activity.

In 1967, the DRBC used this benefit-cost analysis to set dissolved oxygen criterion at $3.5 \mathrm{mg} / \mathrm{L}$ along the river from Philadelphia to Wilmington, where this water quality standard has stood for over four decades. The FWPCA and DRBC were indeed prescient, as multi-billion-dollar investments in Delaware River water pollution control programs have boosted the water quality, as measured by dissolved oxygen-from anoxia during the 1960s, to levels that meet the DRBC criterion of $3.5 \mathrm{mg} / \mathrm{L}$ most of the year (except during the increasingly hot summers).

While the water quality in the Delaware River has recovered over the last half-century, the Partnership for the Delaware Estuary Science and Technical Advisory Committee (PDE STAC) has called for raising the dissolved oxygen standard from $3.5 \mathrm{mg} / \mathrm{L}$, which has stood since the 1960s, to a higher level of protection. A more rigorous standard of at least $5 \mathrm{mg} / \mathrm{L}$ or $6 \mathrm{mg} / \mathrm{L}$ would provide for more year-round protection of anadromous fish, such as the recovering American shad and the nearly extirpated Atlantic sturgeon (just placed on the Federal Endangered Species List). A more rigorous dissolved oxygen standard would also provide protection against atmospheric warming that is projected to increase water temperatures, raise sea levels, and elevate chloride levels, all of which act in combination to reduce dissolved oxygen saturation.

By maximizing least cost agricultural and wastewater BMPs and minimizing higher cost airborne emissions and urban stormwater retrofitting BMPs, we estimate that the annual costs to reduce nitrogen loads by $32 \%$ in the Delaware Basin are reduced by more than $300 \%$, from $\$ 1.66$ billion for Option 1 (reduce $\mathrm{N}$ equally from all sources by $32 \%$ ) to $\$ 449$ million for Option 5 (reduce Agriculture $\mathrm{N}$ by $90 \%$ ). Our interpretation of the nitrogen marginal abatement cost (MAC) curves shows it to be more cost-effective to prioritize upstream investments in agricultural conservation and wastewater treatment, as these controls have lower unit nitrogen reduction costs that are up to an order of magnitude less than the more expensive airborne emission source control and urban/suburban best management practices.

This research concludes, through a marginal abatement cost (MAC) analysis, that it would be cost-effective to raise dissolved oxygen levels to meet a more stringent standard by prioritizing agricultural conservation and some wastewater treatment investments in the Delaware River watershed to remove $90 \%$ of the nitrogen load by 13.6 million $\mathrm{kg} \mathrm{N} /$ year (30 million $\mathrm{lb} \mathrm{N} /$ year) for just 35\% 
(\$160 million) of the $\$ 449$ million total cost. We estimate that the annual costs to reduce nitrogen loads and increase dissolved oxygen to meet a more stringent standard in the Delaware River include $\$ 45$ million for atmospheric NOX reduction, \$130 million for wastewater treatment, \$132 million for agriculture conservation, and $\$ 141$ million for urban stormwater retrofitting.

In 2010 dollars, the annual costs from the 1966 Delaware Estuary economic study range from \$58-\$87 million to achieve summer dissolved oxygen of $4.0 \mathrm{mg} / \mathrm{L}$ to $\$ 180-\$ 209$ million to reach dissolved oxygen of $4.5 \mathrm{mg} / \mathrm{L}$. Estimates from this 50-year-old economic study compare with our 21st century least cost analysis (Option 5), which estimates that an annual investment of $\$ 50$ million is needed to reduce nutrient loads and increase dissolved oxygen levels to $4.0 \mathrm{mg} / \mathrm{L}, \$ 150$ million is needed for dissolved oxygen to reach $4.5 \mathrm{mg} / \mathrm{L}$, and $\$ 449$ million is needed for dissolved oxygen to reach $5.0 \mathrm{mg} / \mathrm{L}$ in the Delaware River.

This economic cost analysis of the pollutant load reductions needed to improve water quality in the Delaware River is influenced by (1) the inverse relationship between water temperature and dissolved oxygen; (2) the delivery fraction of nitrogen; and (3) the groundwater time of travel. Since dissolved oxygen (DO) saturation and water temperature is inversely related, rising water temperatures in the Delaware River to near $30^{\circ} \mathrm{C}\left(86^{\circ} \mathrm{F}\right)$ during summer may depress dissolved oxygen levels without any decrease in nutrient loading, thus offsetting future pollution load reduction efforts. Based on the delivery fraction of nitrogen (i.e., fraction of nitrogen load delivered to the outlet), nitrogen reduction practices should be cost-effectively invested in watersheds close to the estuary that deliver the highest yield of nitrogen. Depending on soil permeability, long groundwater time of travel may occur; therefore, the effects of urban/suburban stormwater and agriculture nitrogen load reduction BMPs in source water many miles from the Delaware River may take months to years to have a positive impact on water quality.

Acknowledgments: We are grateful to the Delaware River Basin Commision and Partnership for the Delaware Estuary in the support of this economic research.

Conflicts of Interest: The authors declare there are no conflicts of interest.

\section{References}

1. Gilbert, M.; Madden, C.J.; Boynton, W.; Flemer, D.; Heil, C.; Sharp, D. Nutrients in Estuaries: Summary Report of National Estuarine Experts Workgroup 2005-2007; EPA Contract No. 68-C-02-91 and EP-6-07-025; United States Environmental Protection Agency: Washington, DC, USA, 2010; p. 188.

2. Stoner, N.K. Memorandum to regional administrators Regions 1-10. In Working in Partnership with States to Address Phosphorus and Nitrogen Pollution through Use of a Framework for State Nutrient Reductions; United States Environmental Protection Agency: Washington, DC, USA, 2011.

3. Schleich, J.; White, D.; Stephenson, K. Cost implications in achieving alternative water quality targets. Water Resour. Res. 1996, 32, 2879-2884. [CrossRef]

4. Evans, B.M. An evaluation of potential nitrogen load reductions to Long Island Sound from the Connecticut River Basin. In A Report to the New England Interstate Water Pollution Control Commission, Lowell, MA; Penn State Institutes of Energy and the Environment: University Park, PA, USA, 2008; p. 66.

5. Chesapeake Bay Program. Chesapeake Bay Watershed Bmp Potential Load Reductions and Cost-Effectiveness Study; Chesapeake Bay Program: Annapolis, MD, USA, 2004.

6. Rabotyagov, S.; Campbell, T.; Jha, M.; Gassman, P.W.; Arnold, J.; Kurkalova, L.; Secchi, S.; Feng, H.; Kling, C.L. Least-cost control of agricultural nutrient contributions to the Gulf of Mexico hypoxic zone. Ecol. Appl. 2010, 20, 1542-1555. [CrossRef] [PubMed]

7. Lyon, R.; Farrow, S. An economic analysis of Clean Water Act issues. Water Resour. Res. 1995, 31, 213-223. [CrossRef]

8. Interstate Commission on the Delaware River Basin. The Delaware River Basin Physical Facts; Interstate Commission on the Delaware River Basin: Philadelphia, PA, USA, 1940.

9. Sharp, J.H.; Church, T.M. Biochemical modeling in coastal waters of the Middle Atlantic States. Limnol. Oceanogr. 1981, 26, 843-854. [CrossRef] 
10. Albert, R.C. The historical context of water quality management for the Delaware Estuary. Estuaries 1988, 11, 99-107. [CrossRef]

11. Mandarano, L.A.; Featherstone, J.P.; Paulsen, K. Institutions for interstate water resources management. J. Am. Water Resour. Assoc. 2008, 44, 136-147. [CrossRef]

12. Sharp, J.H.; Culberson, C.H.; Church, T.M. The chemistry of the Delaware Estuary. General considerations. Limnol. Oceanogr. 1982, 27, 1019-1028. [CrossRef]

13. Sharp, J.H.; Pennock, J.R.; Church, T.M.; Tramontano, J.M.; Cifuetes, L.A. The Estuarine Interaction of Nutrients, Organics, and Metals: A Case Study in the Delaware Estuary; The Estuary as a Filter; Academic Press Inc.: Cambridge, MA, USA, 1984.

14. Scudlark, J.R.; Church, T.M. Atmospheric input of inorganic nitrogen to Delaware Bay. Estuaries Coasts 1993, 16, 747-759. [CrossRef]

15. Sharp, J.H. How the Delaware Estuary works. In Proceedings of the Prepared for Processes Workgroup Meeting, Tiburon, CA, USA, 20 June 2006.

16. Church, T.M.; Sommerfield, C.K.; Velinsky, D.J.; Point, D.; Benoit, C.; Amouroux, D.; Plaa, D.; Donard, F.X. Marsh sediments as records of sedimentation, eutrophication and metal pollution in the urban Delaware Estuary. Mar. Chem. 2006, 102, 72-95. [CrossRef]

17. Bricker, S.; Longstaff, B.; Dennison, W.; Jones, W.; Boicourt, K.; Wicks, C.; Woerner, J. Effects of nutrient enrichment in the Nation's estuaries: A decade of change. In NOAA Coastal Ocean Program Decision Analysis Series No. 26; National Center for Coastal Ocean Science: Silver Spring, MD, USA, 2007; p. 328.

18. Bain, M.; Walter, M.T.; Steenhuis, T.; Brutsaert, W.; Gaetano, A. Delaware River and Catskill Region hydrologic observatory. In Prospectus by the Cornell University Hydrologic Sciences Working Group 2010; Cornell University: Ithaca, NY, USA; p. 10.

19. Sharp, J.H.; Yoshiyama, K.; Parker, A.E.; Schwartz, M.C.; Curless, S.E.; Beauregard, A.Y.; Ossolinski, J.E.; Davis, A.R. A biogeochemical view of estuarine eutrophication: Seasonal and spatial trends and correlations in the Delaware Estuary. Estuaries Coasts 2009, 32, 1023-1043. [CrossRef]

20. Sharp, J.H. Estuarine oxygen dynamics: What can we learn about hypoxia from long-time records in the Delaware Estuary? Limonol. Oceanogr. 2010, 55, 535-548. [CrossRef]

21. Schneider, J. Development of numeric nutrient criteria for waters of the State of Delaware and Delaware Bay/Estuary nutrient dissolved oxygen concerns. In Proceedings of the DRBC Joint Monitoring and Water Quality Advisory Committee Meeting, West Trenton, NJ, USA, 20 February 2007.

22. Sildorff, E.; Fikslin, T.J. Continuing restoration of dissolved oxygen in the Delaware Estuary: Historical data and current efforts. In Proceedings of the 2010 AWRA Conference, Philadelphia, PA, USA, 1-4 November 2010.

23. Kauffman, G.J.; Homsey, A.R.; Belden, A.C.; Sanchez, J.R. Water quality trends in the Delaware River Basin (USA) from 1980 to 2005. Environ. Monit. Assess. 2010, 177, 193-225. [CrossRef] [PubMed]

24. Sharp, J.H.; Cifuentes, L.A.; Coffin, R.B.; Pennock, J.R. The influence of river variability on the circulation, chemistry, and microbiology of the Delaware Estuary. Estuaries 1986, 9, 261-269. [CrossRef]

25. Roman, C.T.; Jaworski, N.; Short, F.T.; Findlay, S.; Warren, R.S. Estuaries of the northeastern United States: Habitat and land use signatures. Estuaries 2000, 23, 743-764. [CrossRef]

26. Delaware River Basin Commission. Administrative Manual Part III Water Quality Regulations with Amendments through July 16, 2008; Delaware River Basin Commission: Ewing Township, NJ, USA, 2008; p. 131.

27. Delaware River Basin Commission. Delaware River and Bay Integrated List Water Quality Assessment; Delaware River Basin Commission: Ewing Township, NJ, USA, 2010; p. 46.

28. Dorfman, R.; Jacoby, H.D.; Thomas, H.A. Models for Managing Regional Water Quality; Harvard University Press: Cambridge, MA, USA, 1972.

29. Maass, A.; Huffschmidt, M.; Dorfman, R.; Thomas, H.; Marglin, S.; Fair, G. Design of Water Resources Systems; Harvard University Press: Cambridge, MA, USA, 1962.

30. Reuss, M. Is it time to resurrect the Harvard Water Program? J. Water Resour. Plan. Manag. Am. Soc. Civ. Eng. 2003, 129, 357-360. [CrossRef]

31. Schaumburg, G.W. Water pollution control in the Delaware Estuary. In Harvard Water Program Discussion Paper No. 67-2; Harvard University: Cambridge, MA, USA, 1967; p. 150.

32. Federal Water Pollution Control Administration. Delaware Estuary Comprehensive Study, Preliminary Report and Findings; Federal Water Pollution Control Administration: Washington, DC, USA, 1966; p. 110. 
33. Thomann, R.V. River Ecology and Man. In The Delaware River-A Study in Water Quality Management; Oglesby, R.T., Carlson, C.A., McCann, J.A., Eds.; Academic Press Inc.: New York, NY, USA, 1972; pp. 99-132.

34. Kneese, A.V.; Bower, B.T. Managing Water Quality: Economics, Technology, Institutions; Resources for the Future: Washington, DC, USA, 1984; p. 328.

35. Johnson, E.L. A study in the economics of water quality management. Water Resour. Res. 1967, 3, $291-305$. [CrossRef]

36. Ad-Hoc Task Force to Evaluate Dissolved Oxygen Requirements of Indigenous Estuary Fish. Dissolved Oxygen Requirements of a "Fishable" Delaware River Estuary; Report to the Delaware River Basin Commission; Delaware River Basin Commission: Trenton, NJ, USA, 1979.

37. Delaware River Fish and Wildlife Management Cooperative. A Fishery Management Plan for the American Shad (Alosa Sapidissimia) in the Delaware River Basin; Delaware River Fish and Wildlife Management Cooperative: New York, NY, USA, 1982; p. 26.

38. Secor, D.; Gunderson, T.E. Effects of hypoxia and temperature on survival, growth, and respiration of juvenile Atlantic sturgeon, Acipencer oxyrincus. Fish. Bull. 1998, 96, 603-613.

39. Campbell, J.G.; Goodman, L.R. Acute sensitivity of juvenile shortnose sturgeon to low dissolved oxygen concentrations. Trans. Am. Fish. Soc. 2004, 133, 772-776. [CrossRef]

40. Moore, R.B.; Johnston, C.M.; Smith, R.A.; Milstead, B. Source and delivery of nutrients to receiving waters in the northeastern and mid-Atlantic regions of the United States. J. Am. Water Resour. Assoc. 2011, 47, 965-990. [CrossRef] [PubMed]

41. Alam, M.J.; Goodall, J.L. Toward disentangling the effect of hydrologic and nitrogen source changes from 1992 to 2001 on incremental nitrogen yield in the contiguous United States. Water Resour. Res. 2012, 48, 1-16. [CrossRef]

42. Preston, S.D.; Alexander, R.B.; Schwarz, G.E.; Crawford, C.G. Factors affecting stream nutrient loads: A synthesis of regional SPARROW model results for the continental United States. J. Am. Water Resour. Assoc. 2011, 47, 891-915. [CrossRef] [PubMed]

43. Environmental Protection Agency. Progress in Water Quality: An Evaluation of the National Investment in Municipal Wastewater Treatment, Chapter 7: Delaware Estuary Case Study; Environmental Protection Agency: Washington, DC, USA, 2000; pp. 7.1-7.26.

44. Scatena, F.N.; Curley, D.; Laskowski, S.; Abbott, K.; Bardin, H.; Shieh, W.; Johnson, J. Water quality trading in the lower Delaware River Basin: A resource for practitioners. In Report to the William Penn Foundation by the Institute for Environmental Studies; University of Pennsylvania: Pennsylvania, PA, USA, 2006; p. 86.

45. Environmental Protection Agency. Revisions to Total Maximum Daily Loads for Nutrient and Low Dissolved Oxygen under High Flow Conditions Christina River Basin, Pennsylvania, Delaware and Maryland; Environmental Protection Agency: Washington, DC, USA, 2006.

46. Jones, C.; Branosky, E.; Selman, M.; Perez, M. How Nutrient Trading Could Help Restore the Chesapeake Bay, WRI Working Paper; World Resources Institute: Washington, DC, USA, 2010; p. 13.

47. Trowbridge, P. Analysis of Nitrogen Loading Reductions for Wastewater Treatment Facilities and Non-Point Sources in the Great Bay Estuary Watershed; New Hampshire Department of Environmental Services: Concord, NH, USA, 2010; p. 27.

48. Wieland, R.; Parker, D.; Gans, W.; Martin, A. Costs and Cost Efficiencies for Some Nutrient Reduction Practices in Maryland; NOAA Chesapeake Bay Office: Annapolis, MD, USA, 2009; p. 58.

49. Environmental Protection Agency. Atmospheric Nitrogen Deposition Loadings to the Chesapeake Bay, an Initial Analysis of the Cost-Effectiveness of Control Options; Environmental Protection Agency: Washington, DC, USA, 1996; p. 29.

50. Van Soesbergen, A.; Brouwer, R.; Baan, P.; Hellegers, P.; Polman, N. Assessing the cost-effectiveness of pollution abatement measures in agriculture, industry and the wastewater treatment sector. In WEMPA Report-07 2007; Water Economic Modelling and Policy Analysis, Institute for Environmental Studies: Amsterdam, The Netherlands, 2007; p. 31.

51. Trench, E.C.T.; Moore, R.B.; Ahearn, E.A.; Mullaney, J.R.; Hickman, R.E.; Schwarz, G.E. Nutrient Concentrations and Loads in the Northeastern United States-Status and Trends, 1975-2003: USGS Scientific Investigations Report 2011-5114; United States Geological Survey: Reston, VA, USA, 2012; p. 169. 
52. Phillips, S.W.; Lindsey, B.D. The Influence of Ground Water on Nitrogen Delivery to the Chesapeake Bay; USGS Fact Sheet FS-091-03; United States Geological Survey: Reston, VA, USA, 2003; p. 6.

53. Claessens, L.; Tague, C.L.; Band, L.E.; Groffman, P.M.; Kenworthy, S.T. Hydro-ecological linkages in urbanizing watersheds: An empirical assessment of in-stream nitrate loss and evidence of saturation kinetics. J. Geophys. Res. Biogeosci. 2009, 114, G04016. [CrossRef] 